Prepared in cooperation with the Wyoming Department of Environmental Quality

\title{
Ecological Status of Wyoming Streams, 2000-2003
}
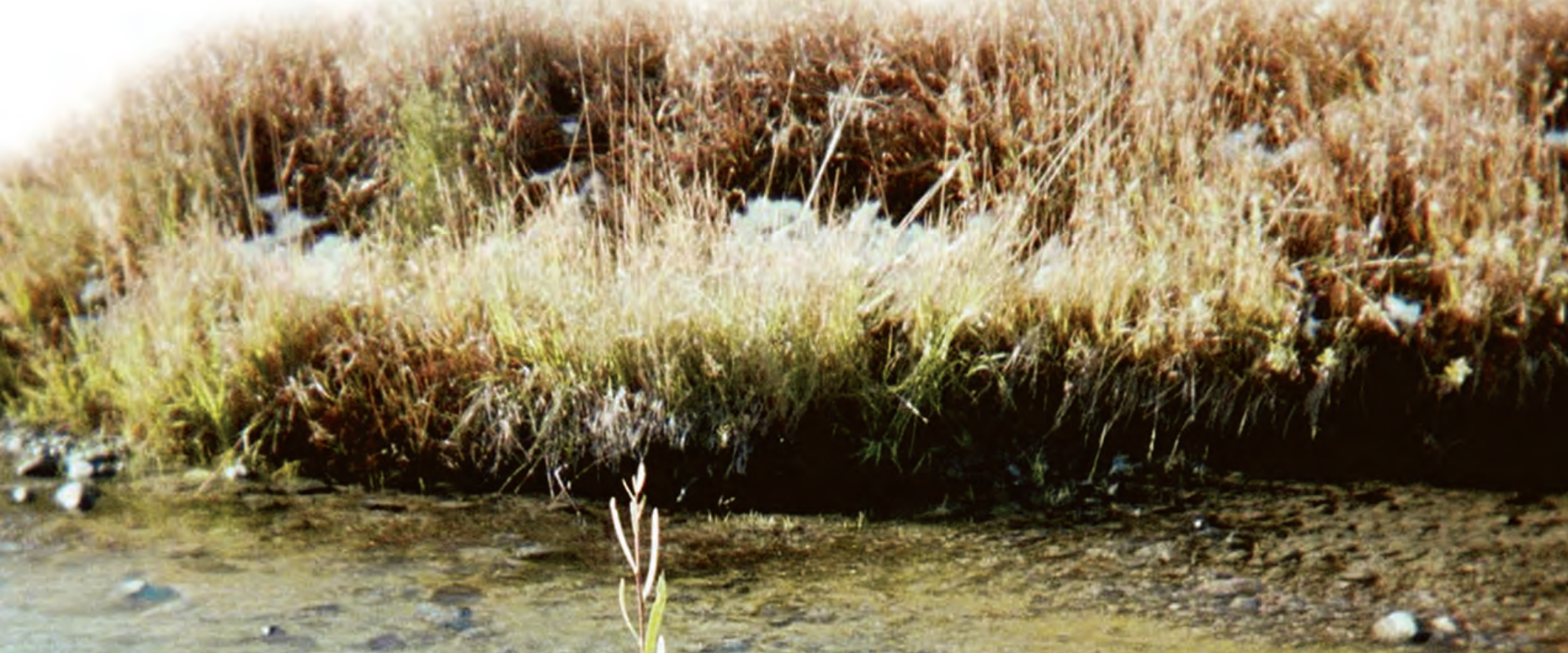

U.S. Department of the Interio

-32
-12

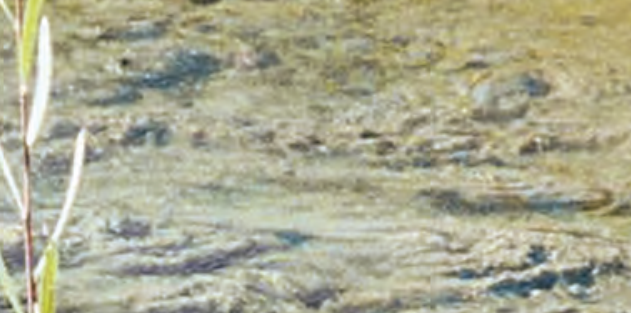

U.S. Geological Surver
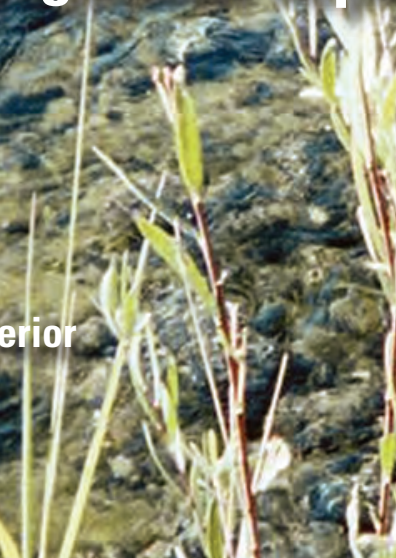

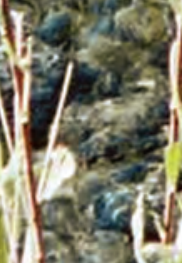

A
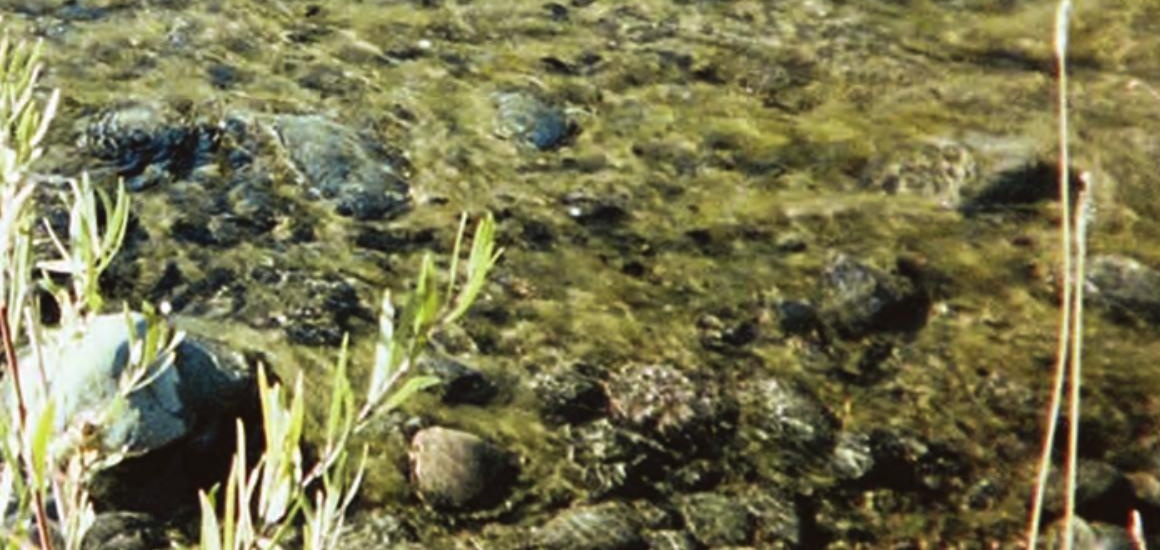
Cover photograph: View of algae on substrate at EMAP sampling site on Meeteetse Creek, northwestern Wyoming, September 2000.

(Photograph by Greg Boughton, U.S. Geological Survey.) 


\section{Ecological Status of Wyoming Streams, 2000-2003}

By David A. Peterson, Eric G. Hargett, Peter R. Wright, and Jeremy R. Zumberge

Prepared in cooperation with the Wyoming Department of Environmental Quality

Scientific Investigations Report 2007-5130 


\section{U.S. Department of the Interior DIRK KEMPTHORNE, Secretary}

\section{U.S. Geological Survey \\ Mark D. Myers, Director}

\section{U.S. Geological Survey, Reston, Virginia: 2007}

For product and ordering information:

World Wide Web: http://www.usgs.gov/pubprod

Telephone: 1-888-ASK-USGS

For more information on the USGS--the Federal source for science about the Earth, its natural and living resources, natural hazards, and the environment:

World Wide Web: http://www.usgs.gov

Telephone: 1-888-ASK-USGS

Any use of trade, product, or firm names is for descriptive purposes only and does not imply endorsement by the U.S. Government.

Although this report is in the public domain, permission must be secured from the individual copyright owners to reproduce any copyrighted materials contained within this report.

Suggested citation:

Peterson, D.A., Hargett, E.G., Wright, P.R., and Zumberge, J.R., 2007, Ecological status of Wyoming streams, 2000-2003: U.S. Geological Survey Scientific Investigations Report 2007-5130, 32 p. 


\section{Contents}

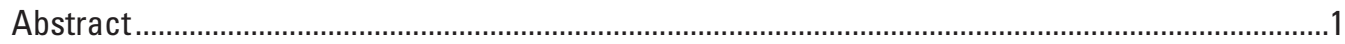

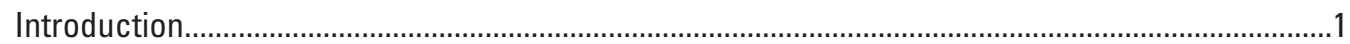

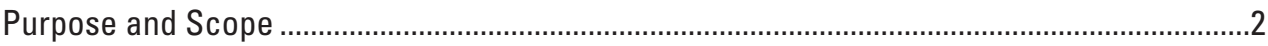

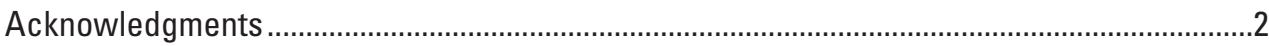

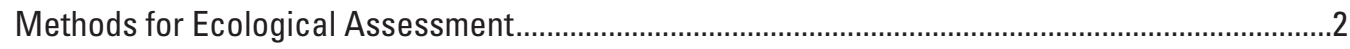

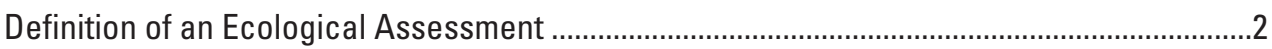

Indicators of Ecological Condition .......................................................................................

Aquatic Vertebrate Index ...................................................................................

Macroinvertebrate Multi-Metric Index.......................................................................

Macroinvertebrate Observed/Expected Index ..............................................................

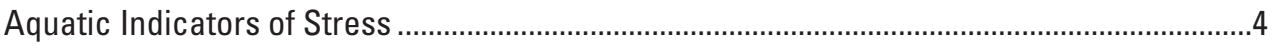

Chemical Stressors ……………..............................................................................

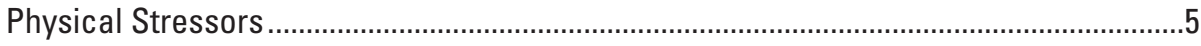

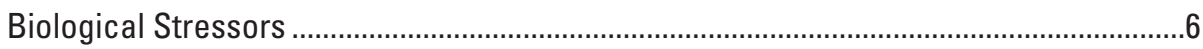

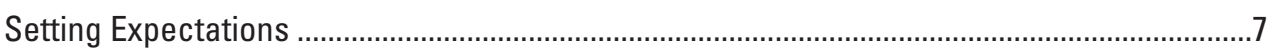

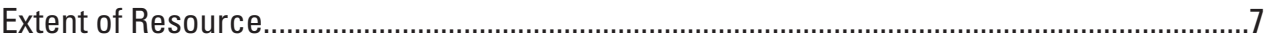

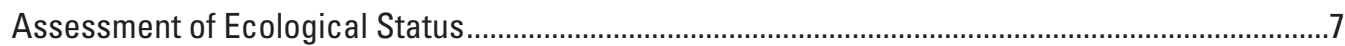

Ecological Indicator Results .........................................................................................10

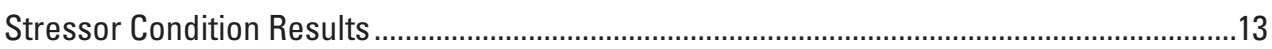

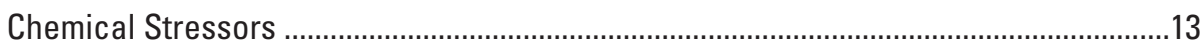

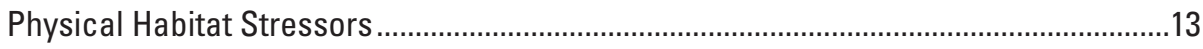

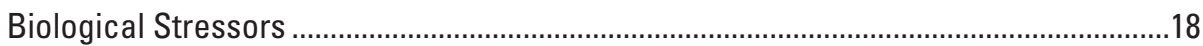

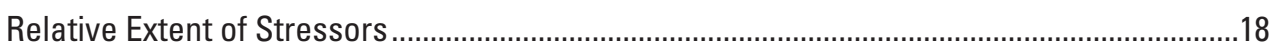

Assessment of Aquatic Life Use Support Using Wyoming Framework...........................................18

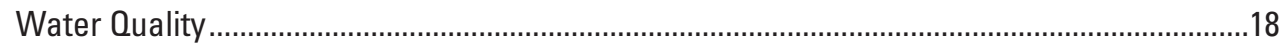

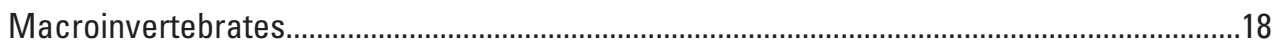

Wyoming Stream Integrity Index Methodology ...............................................................20

Wyoming Observed/Expected Index Methodology........................................................20

Compatibility of West-Wide Data with Wyoming Models..................................................20

Wyoming Stream Integrity Index Biological Condition....................................................21

Wyoming Observed/Expected Index Biological Condition .............................................21

Wyoming Aquatic Life Use Support Decision Matrix ......................................................24

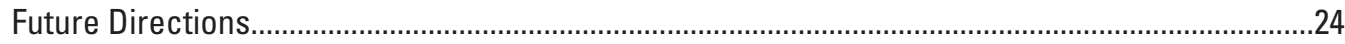

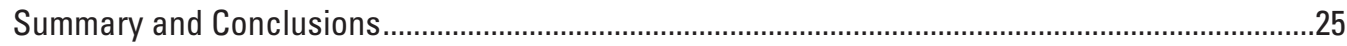

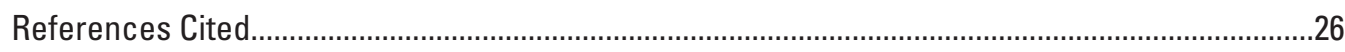

Appendix 1. Location of Environmental Monitoring and Assessment Program wadeable stream sampling sites in Wyoming, 2000-2003 ...............................................30

Appendix 2. Environmental Monitoring and Assessment Program wadeable stream sampling sites in Wyoming, 2000-2003 


\section{Figures}

1. Map showing sampling sites used to assess ecological conditions for the Western Pilot Environmental Monitoring and Assessment Program, 2000-2004

2-8. Graphs showing:

2. Estimated target stream length in relation to access denied, inaccessible, or non-target stream lengths for mountains, xeric, and plains climatic regions, west-wide, and in Wyoming...

3. Summary of results for ecological condition indicators for the Western Pilot Environmental Monitoring and Assessment Program study area, Wyoming, and three climatic regions

4. Summary of results for chemical stressors for Western Pilot Environmental Monitoring and Assessment Program study area, Wyoming, and three climatic regions.

5. Summary of results for physical habitat stressors for the Western Pilot Environmental Monitoring and Assessment Program study area, Wyoming, and three climatic regions

6. Relative extent of chemical, physical, and biological stressors indicating most-disturbed condition for the Western Pilot Environmental Monitoring and Assessment Program study area, Wyoming, and three climatic regions

7. Condition of streams in Wyoming, as indicated by the Wyoming Stream Integrity Index and the Wyoming observed/expected index

8. Aquatic life use attainment of streams in Wyoming, as indicated by a matrix of narrative criteria from the Wyoming Stream Integrity Index and the observed/expected index

\section{Tables}

1. Thresholds used to assign stream-condition categories in the mountains, xeric, and plains climatic regions

2. Invertebrate metric correlations between Environmental Monitoring and Assessment Program reachwide and targeted riffle samples from Wyoming, 2000-2003

3. Wyoming aquatic life use criteria, as determined by the Wyoming Stream Integrity Index and observed/expected index narrative categories. 


\title{
Conversion Factors and Datum
}

\begin{tabular}{lcc}
\hline Multiply & By & To obtain \\
\hline kilometer $(\mathrm{km})$ & Length & \\
\hline & 0.6214 & mile $(\mathrm{mi})$ \\
\hline square meter $\left(\mathrm{m}^{2}\right)$ & Area & \\
\hline
\end{tabular}

Horizontal coordinate information is referenced to the North American Datum of 1983 (NAD83).

Specific conductance is given in microsiemens per centimeter at 25 degrees Celsius $(\mu \mathrm{S} / \mathrm{cm})$.

\section{Abbreviations and Acronyms}

\author{
$\mathrm{mg} / \mathrm{L} \quad$ milligrams per liter \\ $\mu \mathrm{g} / \mathrm{g} \quad$ micrograms per gram \\ ALU aquatic life use \\ EMAP Environmental Monitoring and Assessment Program \\ EMAP-West Western Pilot Environmental Monitoring and Assessment Program \\ IBI Index of Biotic Integrity \\ MMI multi-metric index \\ O/E observed/expected \\ RBS relative bed stability \\ RF3 U.S. Environmental Protection Agency River Reach File 3 (Alpha) \\ RIVPACS River InVertebrate Prediction and Classification System \\ USEPA U.S. Environmental Protection Agency \\ USGS U.S. Geological Survey \\ WDEO Wyoming Department of Environmental Quality \\ WSII Wyoming Stream Integrity Index
}




\title{
Ecological Status of Wyoming Streams, 2000-2003
}

\author{
By David A. Peterson', Eric G. Hargett ${ }^{2}$, Peter R. Wright ${ }^{3}$, and Jeremy R. Zumberge ${ }^{4}$
}

\section{Abstract}

The ecological status of perennial streams in Wyoming was determined and compared with the status of perennial streams throughout 12 States in the western United States, using data collected as part of the Western Pilot Environmental Monitoring and Assessment Program (EMAP-West). Results for Wyoming are compared and contrasted in the context of the entire EMAP-West study area (west-wide) and climatic regions (based on aggregated ecoregions) within Wyoming. In Wyoming, ecological status, estimated as the proportion of the perennial stream length in least disturbed, most disturbed, and intermediate disturbance condition, based on ecological indicators of vertebrate and invertebrate assemblages was similar, in many cases, to the status of those assemblages determined for EMAP-West. Ecological status based on chemical and physical habitat stressors also was similar in Wyoming to west-wide proportions in many cases. Riparian disturbance was one of the most common physical stressors west-wide and in Wyoming. The estimates of riparian disturbance indicated about 90 percent of the stream length in the xeric climatic region in Wyoming was rated most disturbed, compared to about 30 percent rated most disturbed in the mountain climatic region in Wyoming.

Results from analyses using a macroinvertebrate multi-metric index (MMI) and macroinvertebrate ratio of observed to expected taxa (O/E) developed specifically for the west-wide EMAP study were compared to results using a macroinvertebrate MMI and O/E developed for Wyoming. Proportions of perennial stream length in various condition categories determined from macroinvertebrate MMIs often were similar in Wyoming to proportions observed west-wide. Differences were larger, but not extreme, between west-wide and Wyoming O/E models. An aquatic life use support decision matrix developed for interpreting the Wyoming MMI and $\mathrm{O} / \mathrm{E}$ model data indicated about one-half of the stream length statewide achieves the State's narrative aquatic life use criteria, and the remainder of the stream length either exceeds the criteria, indicating partial or non-support of aquatic life

\footnotetext{
${ }^{1}$ U.S. Geological Survey, Cheyenne, Wyoming

${ }^{2}$ Wyoming Department of Environmental Quality, Cheyenne, Wyoming

${ }^{3}$ U.S. Geological Survey, Billings, Montana

${ }^{4}$ Wyoming Department of Environmental Quality, Sheridan, Wyoming
}

uses, or is undetermined. These results provide initial estimates of aquatic life use support at a statewide basis as required for 305(b) reporting, and coupled with current and future State-level probability survey designs, a foundation for tracking conditions over time at multiple scales.

\section{Introduction}

The Clean Water Act (sec. 305b) requires the U.S. Environmental Protection Agency (USEPA), in partnership with States and tribal nations, to compile a biennial report on the status of water quality throughout the Nation. This is a challenging task, in part because data-collection and analysis techniques are not consistent across the Nation (Stoddard, 2001). Therefore, to help address the requirements for section 305b reporting, the Environmental Monitoring and Assessment Program (EMAP) was initiated in the late 1980s to develop the scientific tools necessary to monitor and assess trends of the Nation's aquatic ecological resources with a known statistical confidence (Hughes and others, 2000; U.S. Environmental Protection Agency, 2000). One of the tools developed by EMAP is a statistical, or probability based, design to ensure that sampling sites are representative and that results from the sampling sites can be extrapolated to large areas (for example, States or regional areas) with known confidence limits. Currently (2007), the USEPA has adapted many of the EMAP design and monitoring tools to assess the status of various types of aquatic resources on a rotating basis.

In 1999, a large regional study known as the Western Pilot EMAP (EMAP-West) was initiated (Stoddard, 2001). A principal objective of the EMAP-West study was to test, as well as demonstrate, the use of monitoring and assessment tools developed by EMAP in the diverse array of stream settings in the western United States (McDonald and others, 2002). The EMAP-West study was conducted during 2000-2004 and included collection of more than 1,500 samples from 1,340 perennial streams (Stoddard and others, 2005b) in 12 States-Arizona, California, Colorado, Idaho, Montana, Nevada, North Dakota, Oregon, South Dakota, Utah, Washington, and Wyoming. Sampling sites were located on both wadeable and non-wadeable streams and rivers. A total of 965 sites that were chosen randomly from a probability based design (fig. 1) to be representative of the entire population of flowing waters in the West were used to 
assess ecological condition for the EMAP-West study. Many of the other sites were handpicked as potential reference sites. Both probability and handpicked sites were subjected to a screening process to select a set of final reference sites to represent a least-disturbed condition (Stoddard and others, 2005a; Stoddard and others, 2006).

This study was conducted by the U.S. Geological Survey (USGS) in cooperation with the Wyoming Department of Environmental Quality (WDEQ) to determine the ecological status of perennial streams in Wyoming and to compare the status with that of perennial streams throughout 12 States in the Western United States. Data presented in this report include data collected by the USGS at 71 sites on wadeable streams in Wyoming and data collected by a contractor to the USEPA at 3 sites on non-wadeable streams in Wyoming. Methods used to collect the samples are described by Peck and others (2006) and Lazorchak and others (2000).

Some sites from the probability based design were not sampled because of factors such as physical inaccessibility or lack of access permission from landowners or because the site did not meet specific criteria for perennial streams (for example, dry stream reaches). Those sites were replaced with other sites from the probability based design to maintain the integrity of the design; and to achieve the desired sample size for assessment. Replacing sites and accounting for the sampling status of all sites selected by the probability based design allowed for improved estimates of the extent of the perennial-stream resource and for a more explicit description of that part of the perennial-stream resource for which the results of the assessment could be inferred.

Details regarding the probability based design are presented in Stoddard and others (2005a, 2005b). Data from the Western Pilot EMAP (EMAP-West) study were incorporated with data from the other 36 States in the conterminous United States as part of the Wadeable Streams Assessment that was completed in 2005 (U.S. Environmental Protection Agency, 2006).

\section{Purpose and Scope}

The purpose of this report is to describe ecological status of Wyoming streams during 2000-2003. The first part of this report provides an ecological assessment of perennial streams in Wyoming on the basis of data collected from 71 sites on wadeable streams and 3 sites on non-wadeable streams. These results are placed in context with those from the EMAP-West study at two scales - climatic regions (mountains, xeric, and plains) and the entire EMAP-West study area (operationally termed west-wide in this report). The second part of this report describes the assessment of aquatic life use support (ALU). EMAP tools, such as the probability based design, are used to demonstrate their utility in relation to specific monitoring and assessment techniques and criteria developed by the State of Wyoming. These techniques and criteria include assessments based on ALU designations and ecological indicators of condition based on benthic macroinvertebrate assemblages.

\section{Acknowledgments}

The information in this document has been supported wholly or in part by the USEPA under cooperative agreement CR828154 to the WDEQ. Release of the information has been approved by the National Health and Environmental Effects Research Laboratory.

Dave Peck from the USEPA in Corvallis, Oregon, provided R software scripts and guidance for the ecological assessment, in addition to conducting a technical review of the report. A colleague review by Terry Maret from the USGS improved the quality of the manuscript as did comments from Jack Smith, WDEQ, and Tom Johnson, USEPA. USGS personnel, including Greg Boughton, Stacy Kinsey, Kendra Remley, Laura Gianakos, Andy Massey, Nolan Friday, and others, assisted with field sampling. Bill Schroeder, Karl Hermann, and Tom Johnson from the USEPA assisted with sampling and quality assurance in the field.

\section{Methods for Ecological Assessment}

This section of the report describes methods used for the ecological assessment. Indicators of ecological condition and indicators of chemical and physical stress to biological communities are described. Expectations for determining stream condition and the extent of the resource sampled for this study also are described.

\section{Definition of an Ecological Assessment}

Critical components of the EMAP-West aquatic ecological assessment, as defined by Stoddard and others (2005b), include the condition of the biota in the study area and the relative importance of human-caused stressors. The condition of the biota, or, in a broader sense, the condition of aquatic communities, can be assessed in terms of biological integrity. The need to restore and maintain biological integrity was emphasized in the Clean Water Act of 1972 and led to development of tools such as the Index of Biotic Integrity (IBI; Karr, 1991). In an IBI for fish communities, Karr (1991) used various measures (termed metrics), including species composition, trophic composition, abundance, and condition, to determine the overall health, or integrity, of the community. For example, the presence of lesions on fish might be an indicator of poor health but, when combined with other factors such as the presence of fish species tolerant of poor water quality, these metrics can be used to estimate the overall integrity of the fish community. The multi-metric index (MMI) concept used in this report also measures biotic integrity. The 


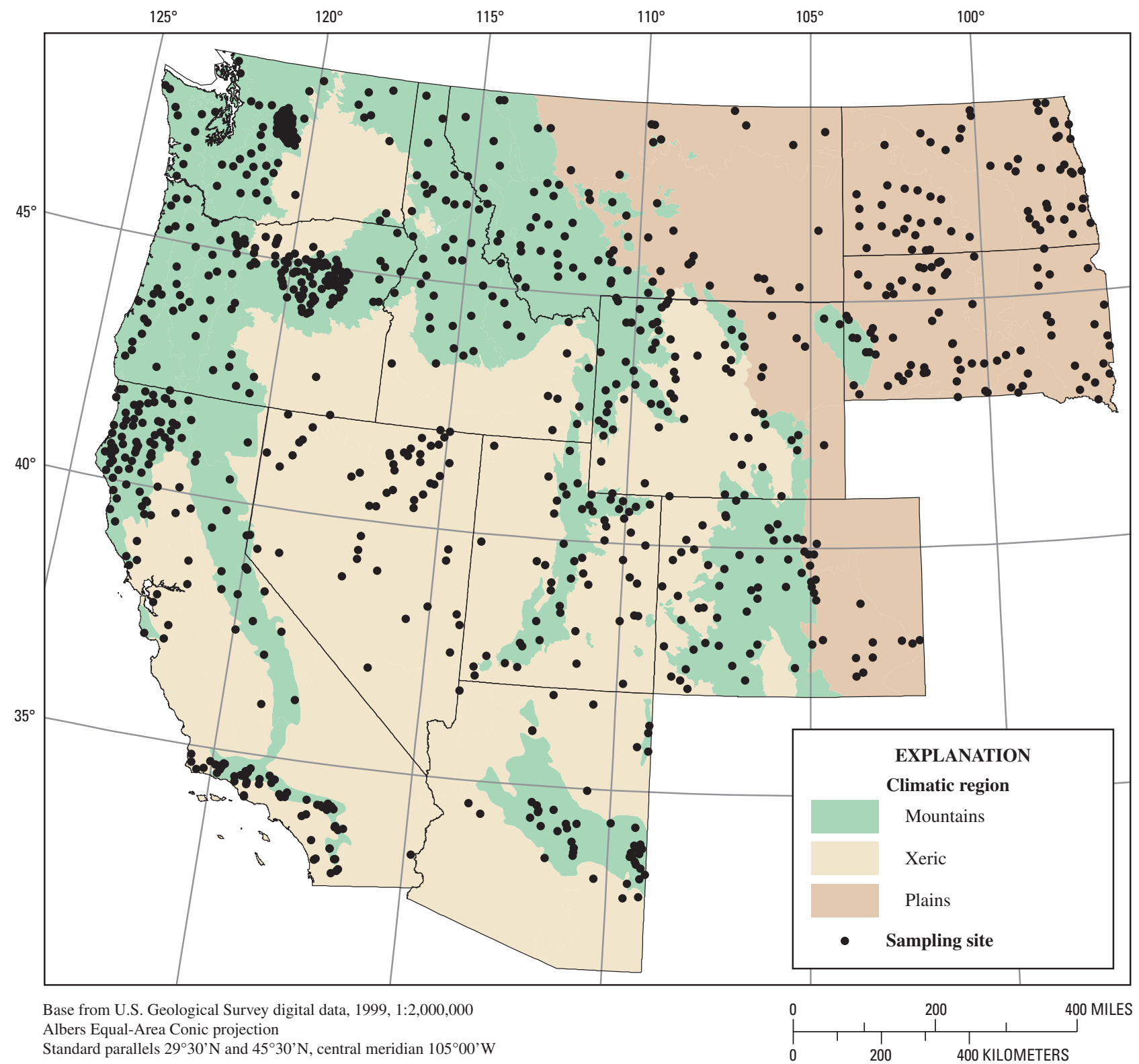

Figure 1. Sampling sites used to assess ecological conditions for the Western Pilot Environmental Monitoring and Assessment Program, 2000-2004.

selection of metrics for the MMI can be based either on the original IBI approach (Karr, 1991) where only biologically important metrics are included in the model or on an empirical approach that selects a subset of several possible metrics that best discriminate between reference and degraded streams (Barbour and others, 1999). The metric scores are calibrated against a set of least-disturbed sites. In the EMAP-West study, least-disturbed sites were identified using a screening procedure similar to that described by Waite and others (2000).
Stressors are chemical, physical, and biological factors that can negatively affect aquatic communities, particularly as influenced by human activities (Stoddard and others, 2005b). Examples of chemical stressors include toxic and carcinogenic organic compounds, nutrients (such as phosphorus or nitrogen), and certain trace elements. Physical stressors include loss of and changes to aquatic habitat, such as channelization and degradation of habitat because of sedimentation resulting from road construction. Biological stressors include non-native or invasive species, such as common carp in streams and rivers and Canada thistle in adjacent riparian zones. 


\section{Indicators of Ecological Condition}

This report focuses on fish and macroinvertebrate communities as indicators of ecological condition. Although EMAP-West study data are available for other aquatic communities, such as periphyton (algae), those data were not complete (as of 2006) and, therefore, are not included in this report.

\section{Aquatic Vertebrate Index}

The aquatic vertebrate index used in this report represents an assessment of the biotic integrity of the fish community, calculated by synthesizing nine metrics into a combined index, or MMI, developed by Stoddard and others (2005a, 2005b) and updated by Whittier and others (2007a). Although metrics based on other vertebrate species (for example, amphibians) were evaluated, all either failed the evaluation process or were less responsive or more variable than metrics based on fish alone. Each of the following nine metrics used in this report represents a metric class or aspect of biotic integrity. The metrics are: (1) habitat (preferred habitat such as benthic or water column); (2) tolerance (general tolerance to physical and chemical stressors); (3) trophic group (for example, omnivore or piscivore); (4) reproductive (habit for each species); (5) composition (relative abundance of different types of taxa); (6) richness (the number of taxa); (7) life history (for example, long-lived or short-lived); (8) alien species (native or introduced); and (9) abundance. Vertebrate MMIs were developed separately for mountain, xeric, and plains climatic regions to avoid the introduction of regional bias and to allow for a consistent and comparable assessment across the entire EMAP-West study area (Stoddard and others, 2005a, 2005b; Whittier and others, 2007a).

\section{Macroinvertebrate Multi-Metric Index}

Scores for macroinvertebrate metrics varied widely across the geography of the west; therefore, Stoddard and others (2005b) developed MMIs separately for mountains, xeric, and plains climatic regions and then used a scoring system that allowed the results from the three MMIs to be compared across the entire EMAP-West study area without the introduction of regional bias. Stoddard and others (2005b) evaluated 76 metrics and then chose 1 metric from each of the following classes to incorporate into each MMI: richness (the number of taxa), diversity (richness of taxa and evenness of distribution of macroinvertebrate abundance among the taxa), composition (relative abundance of select taxa or taxa groups), functional feeding groups (such as scrapers or shredders), habit (for example, clingers or burrowers), and tolerance (to water-quality conditions).

\section{Macroinvertebrate Observed/Expected Index}

Observed/expected (O/E) indices are inherently sitespecific standardized models that estimate the indigenous aquatic macroinvertebrate taxa that are expected to occur at a site in the absence of anthropogenic stress (Barbour and others, 1999). Unlike IBIs or MMIs where model results are derived from or calibrated against stressor gradient(s), O/E indices are based on empirical relations between individual taxon probabilities of capture and natural environmental factors or predictor variables that are derived from data collected from a reference-site network (Hawkins, 2006). An $\mathrm{O} / \mathrm{E}$ index commonly used in the United States to evaluate stream biological conditions is the River InVertebrate Prediction and Classification System (RIVPACS) model described by Hawkins and others (2000), Van Sickle and others (2005), and Hawkins (2006). Predictor variables such as site latitude, site longitude, site elevation, stream gradient, and geology were used to construct and validate the model for the EMAP O/E index (Stoddard and others, 2005a, 2005b). $\mathrm{O} / \mathrm{E}$ values near 1.0 indicate good biological quality whereas values less than 1.0 indicate poor biological quality.

\section{Aquatic Indicators of Stress}

The term stressor as used in this report refers to variables often associated with negative effects, or stresses, to stream ecosystems. Multiple factors such as land use, geology, and climate, can affect concentrations or measures of stressors. Examples of stressors to streams in Wyoming include ammonia (a form of nitrogen), phosphorus, trace elements, habitat degradation, and bacteria (Wyoming Department of Environmental Quality, 2006). The stressors described in this report were selected to complement those described by Stoddard and others (2005b) and represent only a subset of the data available on a statewide and EMAP west-wide basis. The stressors described by Stoddard and others (2005b), in turn, encompass only a subset of the multitude of effects on stream ecosystems.

\section{Chemical Stressors}

Phosphorus is an essential plant nutrient and often is the limiting nutrient for plant or algae growth. Phosphorus added to a stream may stimulate excessive plant or algae growth and lead to detrimental changes in dissolved-oxygen concentrations, $\mathrm{pH}$, or habitat quality (Munn and Hamilton, 2003). Sources of phosphorus to streams include fertilizer, human or animal waste, and natural causes. At one time, phosphorus was a common ingredient in laundry detergents. Use of phosphorus in laundry detergents was banned in the early 1970s because of excessive algae growths in lakes and streams stimulated by large phosphorus concentrations 


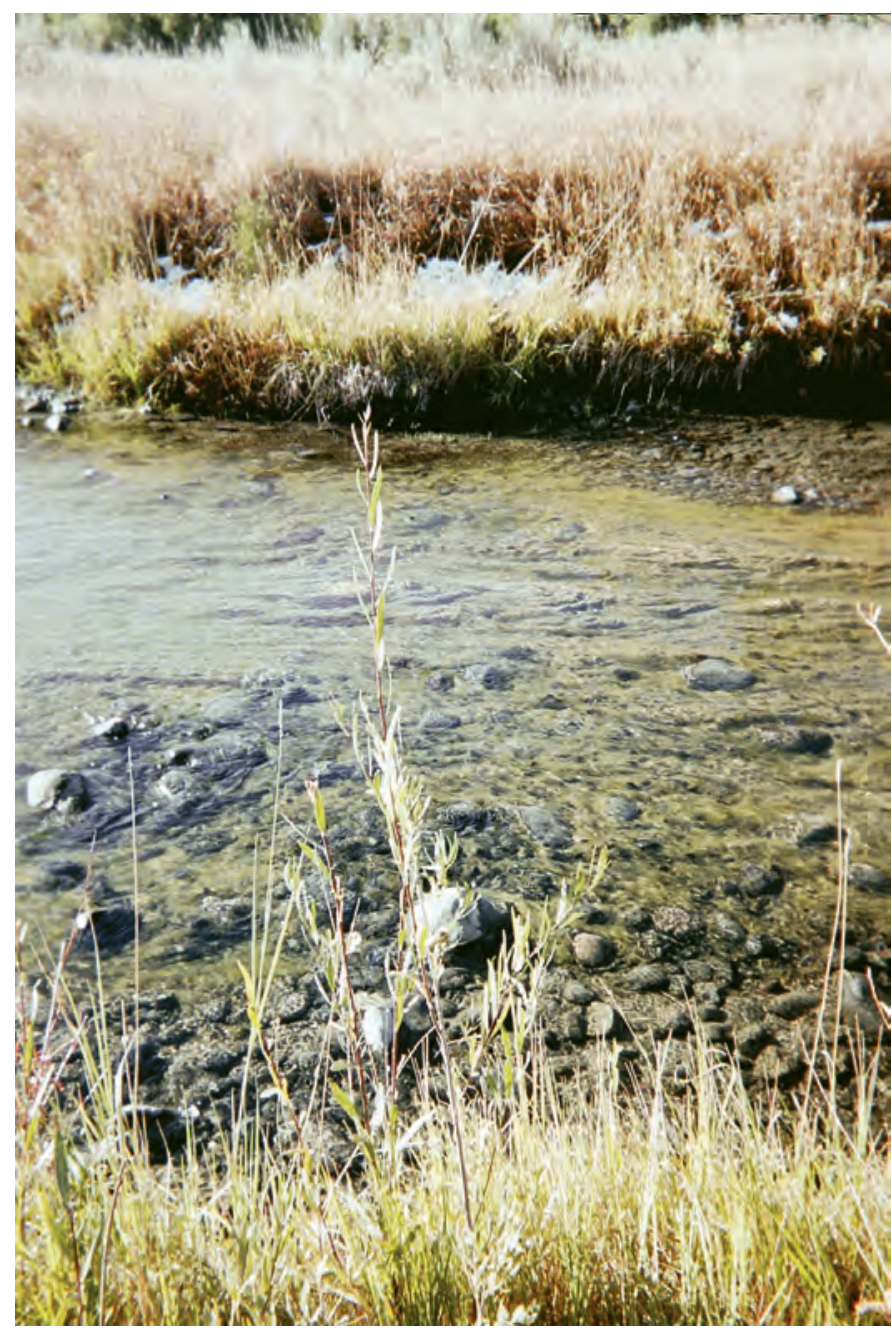

Nutrients, such as phosphorus and nitrogen, stimulate the growth of algae in streams. (Photograph by Greg Boughton, U.S. Geological Survey.)

(Vallentyne, 1974). Phosphorus remains a major ingredient in many automatic dishwasher detergents.

Nitrogen also is an essential element to plant growth and is widely used as a fertilizer on nitrogen-limited soils. Sources of nitrogen to streams include runoff from fertilizer applied to crops and lawns, human or animal waste, and natural causes. Nitrogen has been implicated as a factor in development of algal blooms, such as in streams of the Yellowstone River Basin in Wyoming and Montana (Peterson and Porter, 2002).

Specific conductance is used in this report as an indicator of salinity, or the concentration of dissolved salts. Large specific conductance values generally are associated with poor water quality, which can cause potential negative effects on biological communities and soils in fields and can decrease the palatability for drinking water. Practices that affect specific conductance above naturally occurring background levels include irrigation and road salting.
Mercury in fish tissue is a health issue for humans and wildlife that consume fish (U.S. Environmental Protection Agency, 2007). Sources of mercury include atmospheric deposition, historical gold mining operations, and natural causes. Mercury deposited from the air into water can be converted by bacteria into methyl mercury, a toxic form that accumulates at progressively higher levels of the food chain. In the EMAP-West study, mercury levels in fish were used as an indicator of potential exposure of the stream ecosystem to mercury rather than as a direct measure of exposure to either humans or wildlife (Peterson and others, 2007).

\section{Physical Stressors}

Physical habitat includes structural components of a stream, such as channel dimensions, gradient, and substrate size and type, and riparian zone components, such as riparian vegetative cover and anthropogenic alterations (Kaufmann and others, 1999). Critical habitat features for stream biota include substrate size and sedimentation, and fish cover in pools, under overhanging banks and woody debris, and in other types of structures. Riparian features also affect stream biota by influencing the amount of erosion from the streambank and riparian zones and by shading and providing leaf litter and other inputs to the stream.

Streambed stability is an important indicator of stream integrity because excess sediment creates unstable conditions and can clog fish spawning habitat and interstices in the streambed where macroinvertebrates often reside. Measurements made during this study were used to calculate a measurement of relative bed stability (RBS). The RBS is a ratio of the observed streambed particle size to the expected streambed particle size. The expected streambed particle size is the size of sediment, based on physical characteristics of the stream channel, a stream would be capable of moving during flood stage (Kaufmann and others, 1999). Streambed instability is indicated by both small and large RBS values as compared to the expected range of values for leastdisturbed reference sites. Small RBS values indicate excess fine sediments, whereas large RBS values indicate high bed stability caused by bedrock substrate or bed armoring. Both small and large RBS values are indicators of possible stress in the system. Some anthropogenic activities, such as streambank armoring, removing riparian vegetation, agriculture, road building, logging, and grazing, cause streambed instability. Other anthropogenic activities, such as the construction of dams, interrupt the flow of sediment and can cause armored streambeds.

Habitat complexity (Kaufmann and others, 1999) is used in this report as a measure that sums the amount of instream habitat (in terms of different types of cover) within one meter of the water surface. All living organisms, including fish and macroinvertebrates, have habitat requirements for survival. 


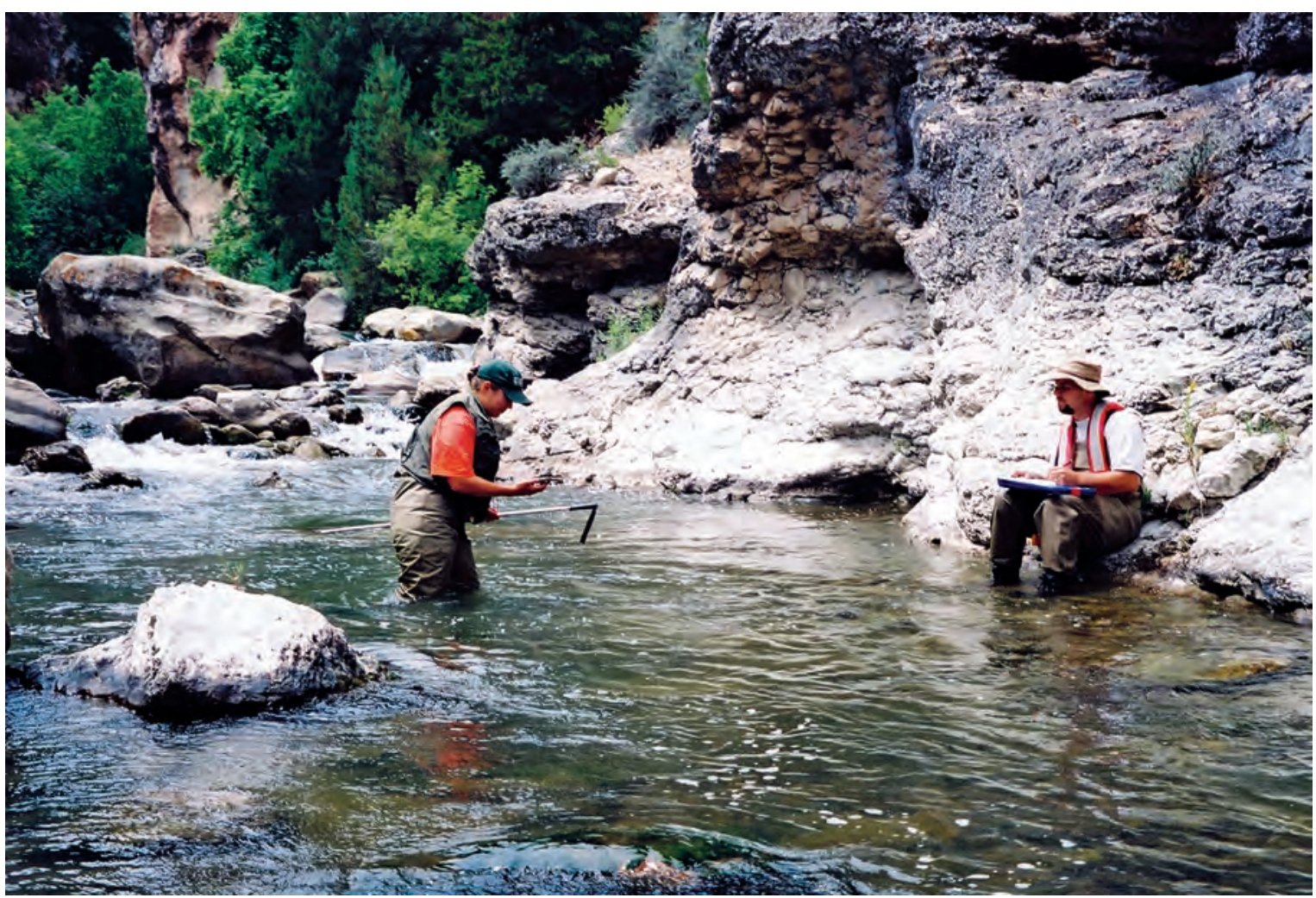

Environmental Monitoring and Assessment Program crew estimating substrate particle size while making habitat measurements. (Photograph by Stacy Kinsey, U.S. Geological Survey.)

Increasing complexity of instream habitat generally correlates with more diverse fish and macroinvertebrate assemblages. Instream habitat features quantified by EMAP crews include boulders, undercut banks, small and large woody debris, macrophytes, filamentous algae, in-channel live trees or roots, and overhanging vegetative cover.

Riparian vegetation grows along stream corridors. These corridors are transition or buffer zones between terrestrial and aquatic systems. When a riparian area is healthy and has complex, multilayered vegetation, the area performs many vital functions. Vegetation holds soils along streams (thus reducing erosion), captures surface flow (thus encouraging ground-water recharge and sustained late-summer flows), and reduces flooding while filtering out sediment, excess nutrients, and other potential contaminants. Trees and shrubs provide stream shading, which helps to control stream temperature variations. Riparian vegetation also provides food, in the form of leaf litter, seeds, insects, and deadfall, for the aquatic system. The litter and deadfall also can provide additional habitat for fish and macroinvertebrates. This study measured the health of riparian areas by evaluating structural complexity (Kaufmann and others, 1999). Percentages of woody cover from the ground layer, woody shrubs, and canopy trees were summed and evaluated.
Riparian disturbance is used in this report as a direct measure of human disturbance in proximity to a river or stream. A total of 11 human land-use activities (logging, mining, buildings, roads, landfills, riprap, pavement, pipes, lawn, row crops, and pasture) were evaluated for presence and proximity to the riparian area. The evaluations were used to construct an index of values that range from 0 to 6 , where the minimum indicates no observed disturbance, and the maximum indicates either four or more types of disturbance observed in the stream or six types of disturbance observed on the bank at all 22 plots where observations were made at a site (Stoddard and others, 2005a, 2005b).

\section{Biological Stressors}

Non-native biota can stress biological communities through competition for resources and the ability of nonnatives to proliferate in the absence of natural predators. An example of a biological invader is the New Zealand mudsnail (Potamopyrgus antipodarum), which has invaded streams in the western part of Yellowstone National Park and has had detrimental effects on native invertebrate communities (Richards, 2002). Other examples of non-natives in streams of Wyoming include the common carp (Cyprinus carpio) 
and game fish such as the brown trout (Salmo trutta) and smallmouth bass (Micropterus dolomieu). Introduction of non-native game fish is a societal issue because the benefits of recreational fishing opportunities are accompanied by potential effects to native communities and to biological integrity as defined in the Clean Water Act.

\section{Setting Expectations}

Expectations for stream condition can be determined by comparing the test-site condition to the reference or baseline condition used to provide the point of comparison (see, for example, Stoddard and others, 2006; Whittier and others, 2007b). In the EMAP-West study report, Stoddard and others (2005b) defined a reference condition for such comparisons with caveats. They recognized that stream conditions today might be different from conditions 50 years ago, or perhaps hundreds of years ago, because of anthropogenic influences. Stream-condition categories-least disturbed, most disturbed, and intermediate-were designated on the basis of conditions that exist today (Stoddard and others, 2006). Reference conditions were determined using chemical-constituent and habitat measurements such as measurements of nutrients, chloride, turbidity, and excess fine sediments according to Waite and others (2000). To avoid circularity, biological indicators were not used to determine the reference condition.

The concentrations, or thresholds, that define the streamcondition categories (least disturbed, most disturbed, and intermediate) were determined separately for each of the three climatic regions (mountains, xeric, and plains). The thresholds that Stoddard and others (2005b) defined for the climatic regions across the EMAP-West study area are used in this report for the same three climatic regions in Wyoming (table 1), which hereafter are referred to as the mountains, the xeric region, and the plains. The statistical process used to determine thresholds is described in detail by Stoddard and others (2005a, 2005b). In the mountains and xeric region, the concentration or value corresponding to the 25 th percentile of the reference site distribution was used as the threshold for the least-disturbed condition, and the 5th percentile was used as the threshold for the most-disturbed condition. In the plains, the 50th and 25th percentiles generally were used as thresholds for the least-disturbed and most-disturbed conditions, respectively. The percentiles were less in the plains because "it is extremely difficult to find streams that have not been altered by grazing, farming, removal or modification of riparian forests, or roads" (Stoddard and others, 2005b, p. 42). Concentrations or values between the least-disturbed and most-disturbed threshold levels listed in table 1 were assigned to an intermediate condition category, with the exception of mercury in fish tissue that has only one threshold.

\section{Extent of Resource}

Streams sampled during the EMAP-West study were selected from the perennial stream network represented in the USEPA River Reach File (known as RF3). The RF3 file is based on a digitized version of the USGS 1:100,000-scale topographic maps. The total length of streams labeled as perennial in the RF3 file for the EMAP-West study area is about 629,000 kilometers (km) (Stoddard and others, 2005b). About 208,000 km, or about one-third of the total stream length, subsequently was determined to be nontarget (fig. 2). The nontargeted stream length is the stream length that was determined in the field to have intermittent flow, wetland areas, or irrigation canals. Stoddard and others (2005b, p. 14) stated that, "This is an important finding for the States of the West, who are required to report on the condition of all perennial streams under their jurisdiction; West-wide, the total perennial stream resource is overestimated by one-third in RF3."

For Wyoming, 50,764 km of stream length is listed as perennial in the RF3 file. The nontarget stream length for Wyoming is about $13,100 \mathrm{~km}$, or 26 percent of the total stream length. The access denied category shown in figure 2 indicates the stream length for which landowners did not allow crews to access the sampling site (3,689 $\mathrm{km}$ in Wyoming), and the inaccessible category indicates the stream length where physical barriers prevented access to the site $(801 \mathrm{~km}$ in Wyoming). The stream lengths in the access denied and inaccessible categories represent a part of the target stream length that cannot be assessed.

Most of the perennial stream length was in the mountains, both west-wide and in Wyoming. The perennial stream length in Wyoming totaled $30,032 \mathrm{~km}$ in the mountains, $15,751 \mathrm{~km}$ in the xeric region, and less than 5,000 km in the plains. Because of the probability based design of the study and random selection of sampling sites based on stream length, more sampling sites in Wyoming were located in the mountains ( 38 sites) than in either the xeric region ( 29 sites) or the plains ( 7 sites).

\section{Assessment of Ecological Status}

The ecological assessment provides information about the status of aquatic communities and stressors that act upon those communities using data and assessment techniques from the EMAP-West study. An overview of the results from the EMAP-West study is given by Stoddard and others (2005b), and a detailed description of the results and the methods and statistical techniques used is given by Stoddard and others (2005a). 


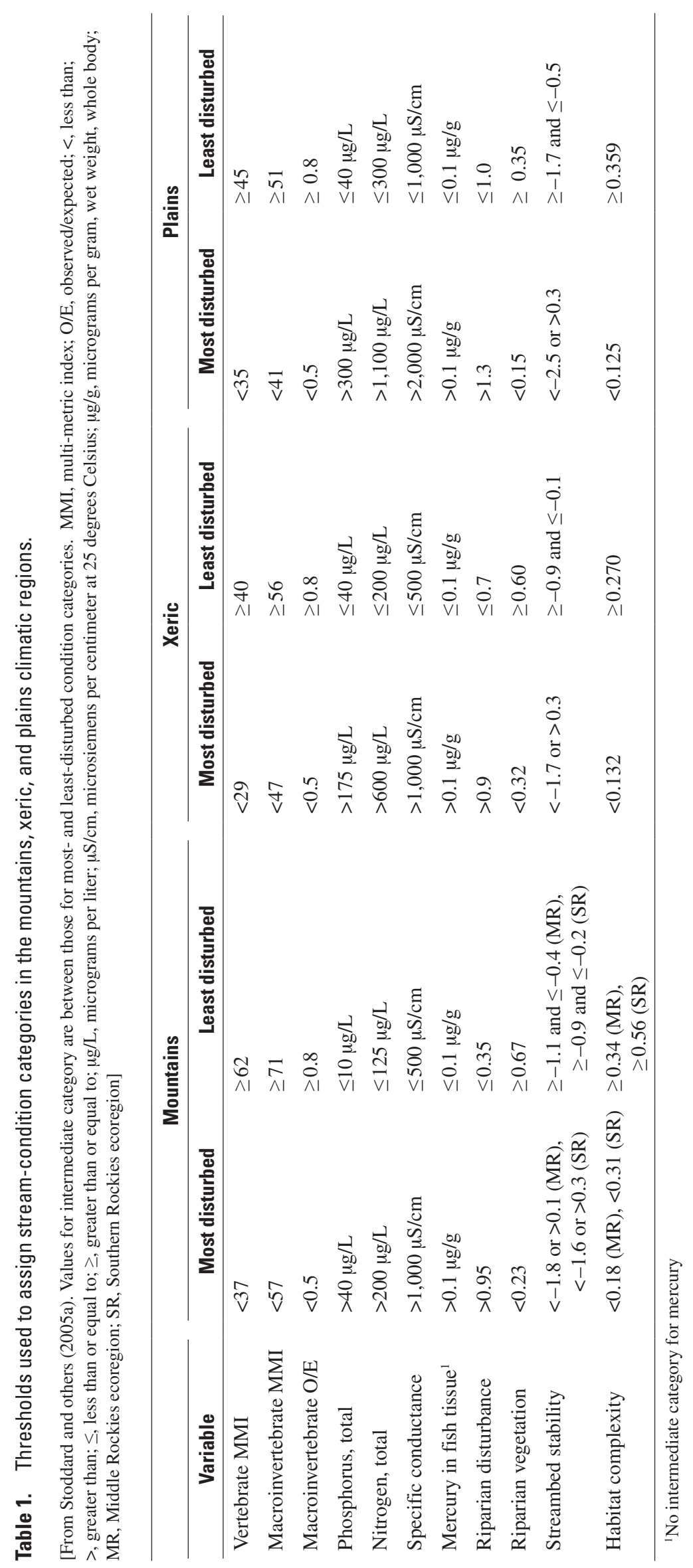




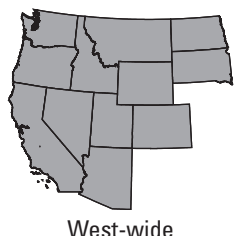

Total 628,624 kilometers

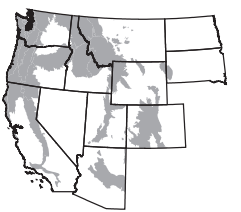

West-wide mountains Total 401,622 kilometers

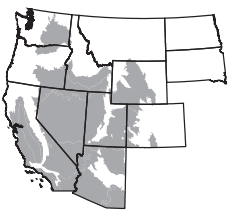

West-wide xeric Total 157,486 kilometers

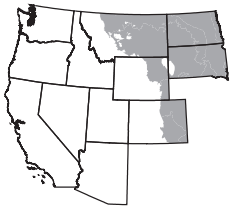

West-wide plains Total 69,516 kilometers

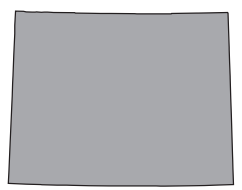

Wyoming Total 50,764 kilometers

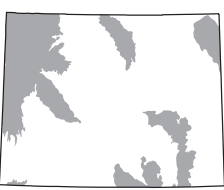

Wyoming mountains Total 30,032 kilometers

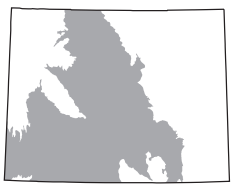

Wyoming xeric Total 15,751 kilometers

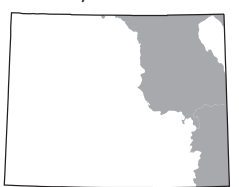

Wyoming plains Total 4,981 kilometers
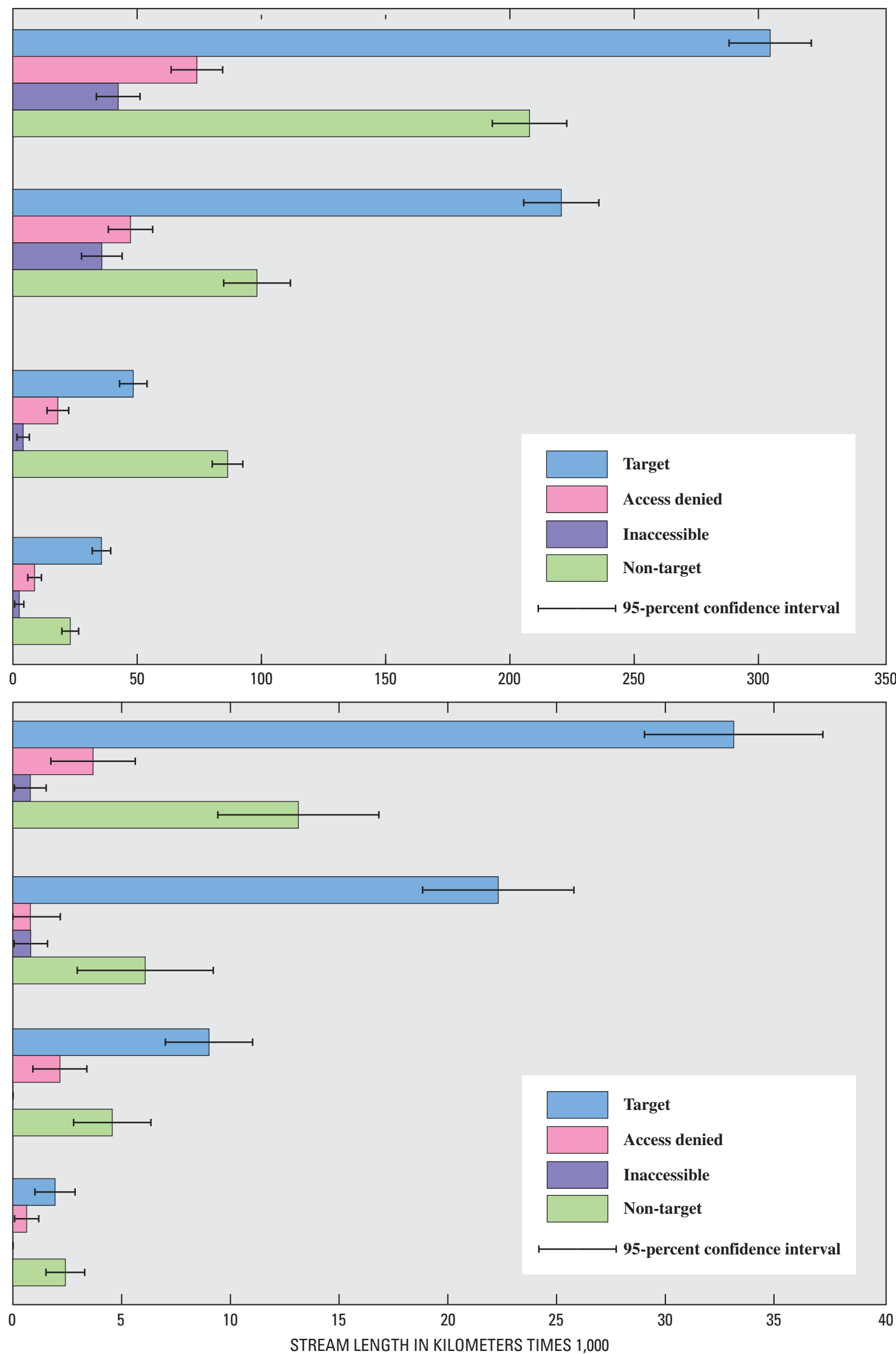

Figure 2. Estimated target stream length in relation to access denied, inaccessible, or non-target stream lengths for mountains, xeric, and plains climatic regions, west-wide, and in Wyoming. 


\section{Ecological Indicator Results}

The biotic integrity of aquatic vertebrate communities, based on an MMI composed of nine measures of the fish community, indicated more stream length was in the leastdisturbed condition than in either an intermediate or mostdisturbed condition west-wide (fig. $3 A$ ). In each of the stream-condition categories, the percentages of stream length in Wyoming (statewide) were similar (within the 95-percent confidence interval) to the percentages west-wide. The 95-percent confidence intervals shown in $3 A$ are larger for Wyoming than those west-wide because there are fewer sites statewide in Wyoming than west-wide.

In the mountains, the aquatic vertebrate MMI indicated more of the stream length was in the least-disturbed condition (about 50 percent) than in either an intermediate or mostdisturbed condition both west-wide and in Wyoming (fig. $3 B$ ). The percentage of stream length in a least-disturbed condition was larger in the mountains than in either the xeric region or plains.

In the xeric region, the aquatic vertebrate MMI indicated the percentage of stream length in a least-disturbed condition in Wyoming was similar to that west-wide (about 30 percent, fig. $3 C$ ). Wyoming had a smaller percentage of stream length in a most-disturbed condition (about 25 percent) and a greater percentage of stream length in an intermediate condition (about 30 percent) than west-wide, but the differences were within the 95-percent confidence intervals.

In the west-wide plains, the percentage of stream length in a most-disturbed condition was larger (about 50 percent) than that in the other categories. In the Wyoming plains, only seven sites were sampled, so study results cannot be interpreted with any degree of confidence-results are presented herein for illustration and completeness only (fig. 3D).

The biotic integrity of the aquatic vertebrate community was not assessed for 20 to 30 percent of the stream length west-wide and in Wyoming because of either not having a permit to collect fish or because no fish were present in the stream. Permits to collect fish sometimes were not issued because of concerns about the effects on endangered species, such as bull trout (Salvelinus confluentus), that occur in some of the western States. In Wyoming, small streams without fish were the primary cause of no data. These streams could be naturally fishless instead of severely affected by human disturbance. For both cases (no collection permits and small, fishless streams), the stream lengths could not be assessed for condition, and the results of the assessed stream lengths should not be extrapolated to the stream lengths that were not assessed (Stoddard and others, 2005b).

The biotic integrity of the macroinvertebrate communities, expressed as the macroinvertebrate MMI, indicated more than 50 percent of the stream length west-wide was in a least-disturbed condition and about 20 percent of the stream length was in an intermediate condition (fig. 3A). In Wyoming, about 40 percent of the stream length was in a least-disturbed condition and about 40 percent was in an intermediate condition. A similar pattern was observed in the mountains (fig. $3 B$ ); the percentage of stream length in a least-disturbed condition in Wyoming (about 35 percent) was smaller than that west-wide and the percentage in an intermediate condition in Wyoming (about 45 percent) was larger than that westwide. In the xeric region (fig. $3 C$ ), the percentage of stream length in a least-disturbed condition in Wyoming (about 52 percent) was larger than that west-wide (about 36 percent). About 25 percent of the stream length in Wyoming was in a most-disturbed condition and about 50 percent of the stream length west-wide was in a most-disturbed condition. In the plains, about 40 percent of the stream length west-wide was in a least-disturbed condition (fig. 3D).

The loss of macroinvertebrate taxa, or the O/E index, indicated a least-disturbed condition predominated both west-wide and in Wyoming and in the climatic regions both west-wide and in Wyoming. Percentages of stream length in a least-disturbed condition generally were similar west-wide and in Wyoming and in each climatic region (fig. 3). Stoddard and others (2005b) indicated the $\mathrm{O} / \mathrm{E}$ index is a good indicator of biotic integrity because the $\mathrm{O} / \mathrm{E}$ results from their EMAP-West study were in close agreement with the macroinvertebrate MMI from their study. In Wyoming, the O/E index and the MMI did not agree as closely as in the EMAP-West study. Discrepancies in biological condition between indicators such as the MMI and $\mathrm{O} / \mathrm{E}$ index can be common and likely arise from differences in either the biological and/or statistical properties of the indicators (Hawkins, 2006). Application of indicators developed to assess biological condition at large spatial scales, such as those developed for the EMAPWest study, also may have some limits in their application to Wyoming where biotic and abiotic conditions unique to the State may not be fully represented in the design of the indicator. Regardless of the differences between the EMAP $\mathrm{MMI}$ and $\mathrm{O} / \mathrm{E}$ index indicators, both models provide a similar biological assessment of Wyoming streams. 

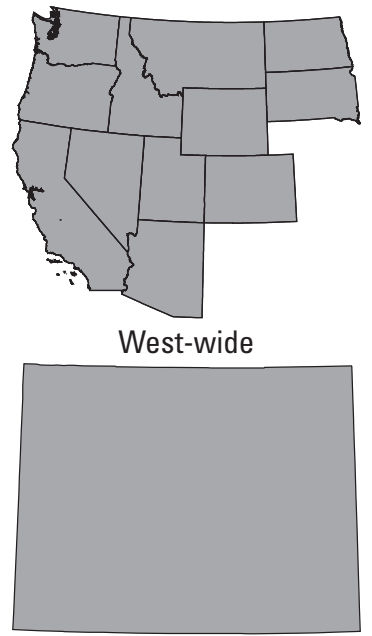

Wyoming

B

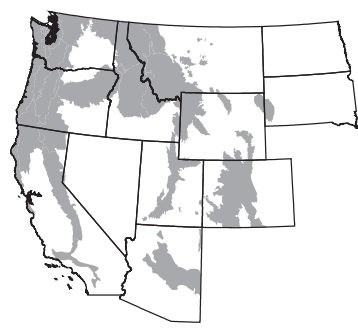

West-wide mountains

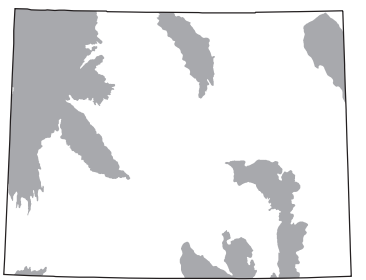

Wyoming mountains
Biotic integrity of

aquatic vertebrates (MMI)

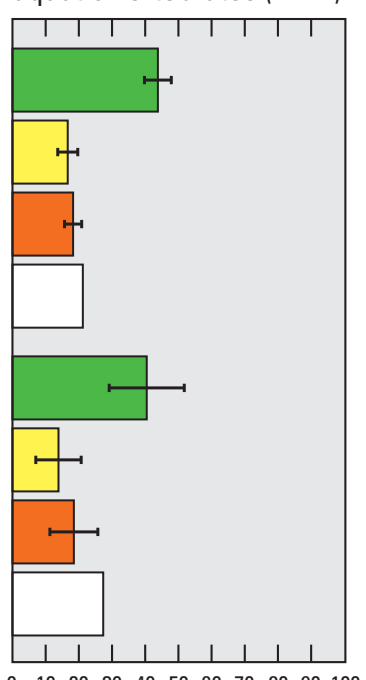

$\begin{array}{lllllllllll}0 & 10 & 20 & 30 & 40 & 50 & 60 & 70 & 80 & 90 & 100\end{array}$

Biotic integrity of macroinvertebrates (MMI)

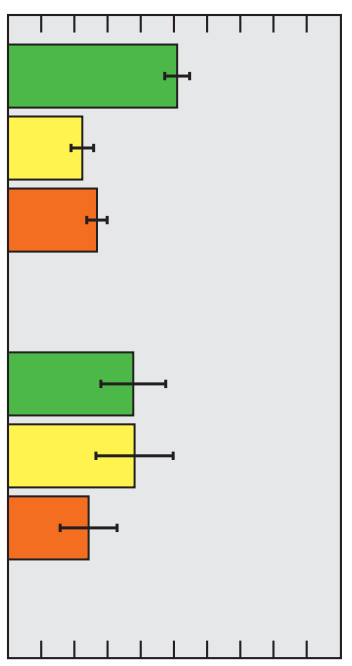

Loss of macro-

invertebrate taxa $(0 / E)$

PERCENTAGE OF STREAM LENGTH IN REGION
Biotic integrity of aquatic vertebrates (MMI)

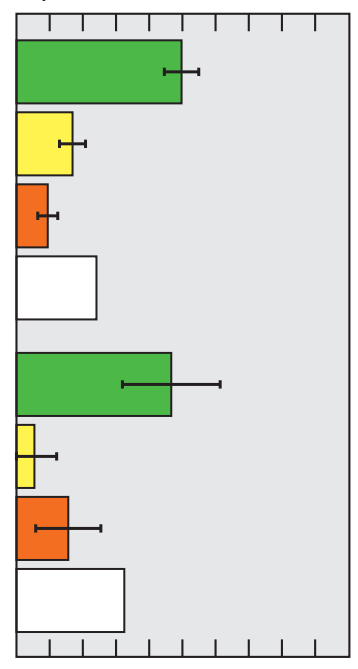

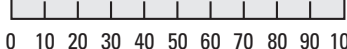

Biotic integrity of
macroinvertebrates (MMI)

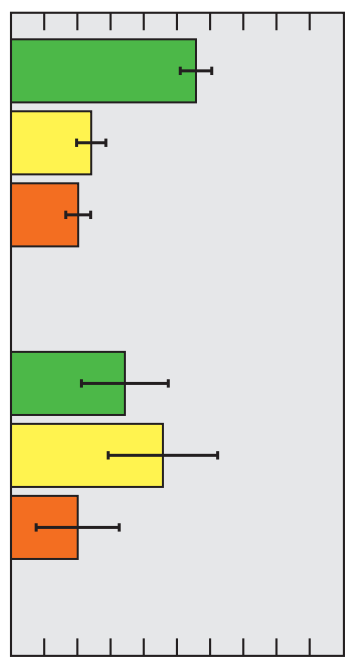

Loss of macroinvertebrate taxa $(0 / E)$

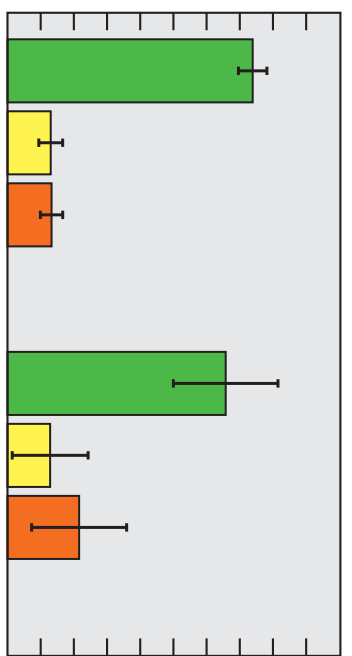

PERCENTAGE OF STREAM LENGTH IN REGION

\section{EXPLANATION}

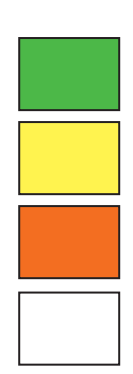

Condition category

95-percent confidence interval

Least disturbed

MMI Multi-metric index

Intermediate

O/E Observed/expected

Most disturbed

No data or no collection permit

Figure 3. Summary of results for ecological condition indicators for the Western Pilot Environmental Monitoring and Assessment Program study area, Wyoming, and three climatic regions. 
C
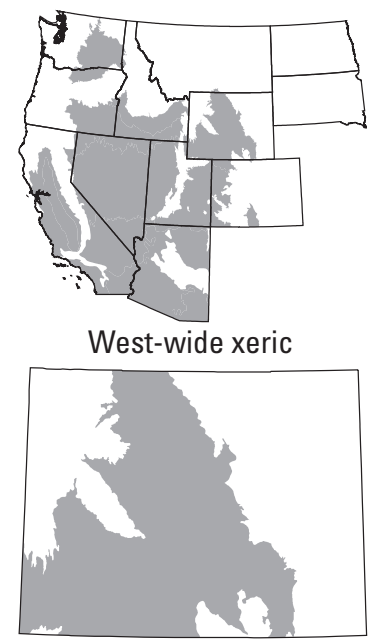

Wyoming xeric
Biotic integrity of aquatic vertebrates (MMI)

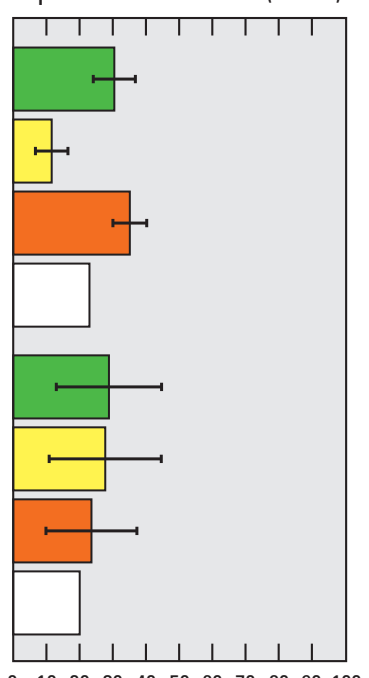

$\begin{array}{lllllllllll}0 & 10 & 20 & 30 & 40 & 50 & 60 & 70 & 80 & 90 & 100\end{array}$
Biotic integrity of macroinvertebrates (MMI)

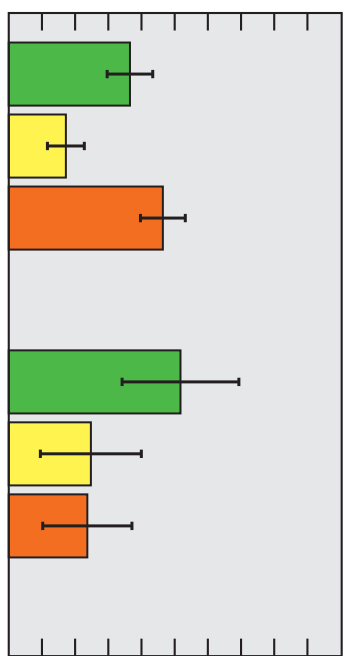

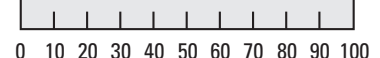
Loss of macroinvertebrate taxa (0/E)

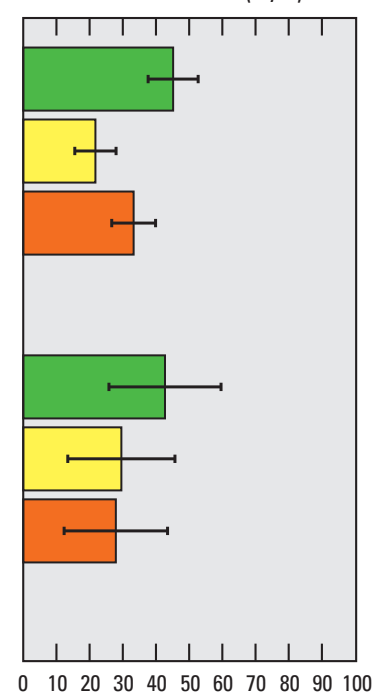

PERCENTAGE OF STREAM LENGTH IN REGION

D

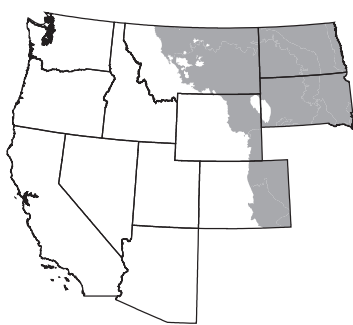

West-wide plains

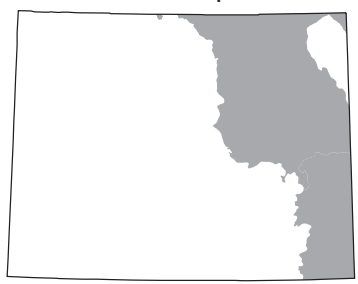

Wyoming plains
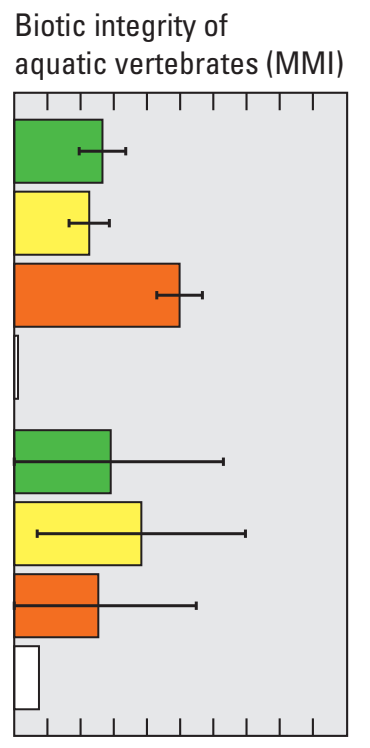

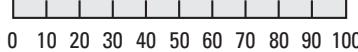

Biotic integrity of

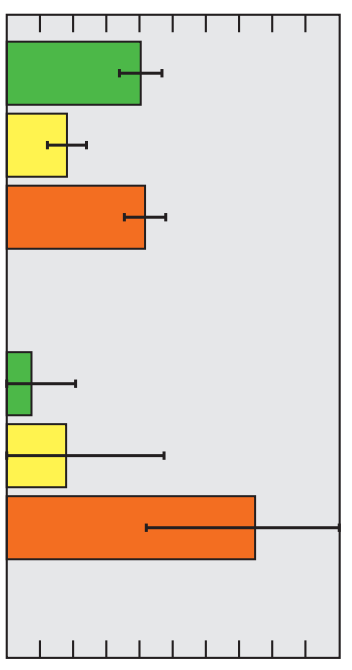

oss of macro-

invertebrate taxa (0/E)

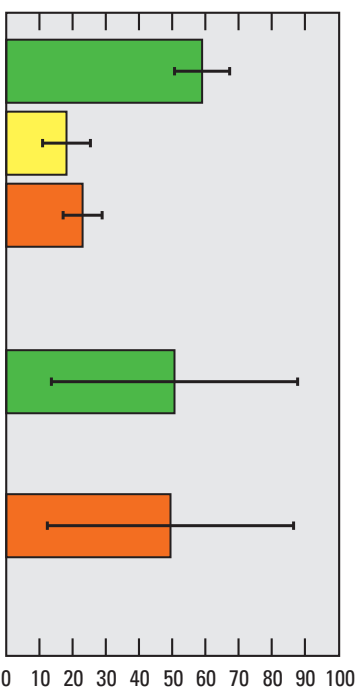

macroinvertebrates (MMI)

PERCENTAGE OF STREAM LENGTH IN REGION

\section{EXPLANATION}

\begin{tabular}{|l|l|}
\hline & Condition category \\
Least disturbed \\
\hline & Intermediate \\
\hline & Most disturbed \\
\hline & $\begin{array}{l}\text { No data or no collection } \\
\text { permit }\end{array}$
\end{tabular}

Figure 3. Summary of results for ecological condition indicators for the Western Pilot Environmental Monitoring and Assessment Program study area, Wyoming, and three climatic regions.-Continued 


\section{Stressor Condition Results}

This section presents the results of chemical, physical habitat, and biological stressors to the biological communities. Stressor conditions are described for west-wide, statewide, and climatic region categories.

\section{Chemical Stressors}

About 50 percent of the stream length west-wide and in Wyoming was in a least-disturbed (good) condition for phosphorus (fig. 4A). The percentage of stream length affected by phosphorus (most disturbed) was larger in the Wyoming mountains than in the west-wide mountains but smaller in the Wyoming xeric region than in the west-wide xeric region (fig. $4 B, C$ ). In the Wyoming xeric region, no streams were in a most-disturbed condition for phosphorus. An intermediate condition predominated in the plains, both west-wide and in Wyoming (fig. 4D).

Percentages of stream length in the various streamcondition categories for nitrogen in Wyoming were similar to percentages west-wide (fig 4A). About 40 percent of the stream length west-wide and in Wyoming was in a leastdisturbed (good) condition for nitrogen (fig. 4A). Percentages in the Wyoming mountains also were similar to those in the west-wide mountains (fig. 4B). About 10 percent of the stream length in the Wyoming xeric region was in a most-disturbed condition, which is a smaller (better) percentage than the nearly 30 percent of stream length estimated for the west-wide xeric region (fig. $4 C$ ). Most of the stream length in the plains was in a most-disturbed or intermediate condition in both west-wide and Wyoming (fig. 4D).

Specific conductance measurements indicated a large percentage of stream length (about 80 percent) was in a leastdisturbed condition west-wide and in Wyoming as well as in the west-wide and Wyoming mountains and xeric regions (fig. 4). More than 95 percent of the stream length was in a least-disturbed condition in the west-wide mountains (fig. 4B). The plains (fig. $4 D$ ) had a smaller percentage (40 to 50 percent) of stream length in a least-disturbed condition in both west-wide and Wyoming than did the other climatic regions.

Mercury concentrations in fish-tissue samples indicated as much as 60 to 70 percent of the stream length in Wyoming was in a least-disturbed condition (fig. 4). Concentrations in the least-disturbed stream length were less than the 0.1-microgram per gram $(\mu \mathrm{g} / \mathrm{g})$ criterion for the protection of the American river otter Lontra canadensis (Lazorchak and others, 2003; Peterson and others, 2007). The percentage of stream length in Wyoming in a least-disturbed condition was similar to or larger than the percentage west-wide and the percentages in the west-wide mountains, xeric region, and plains. Fish samples were either a composite of multiple, small fish of a single species per site or individual specimens of large fish. The fish species selected in Wyoming generally were not piscivores (fish-eating) because of a lack of availability. Piscivores, such as walleye and river otter, tend to accumulate mercury and have larger concentrations of mercury than their prey, such as the minnows, suckers, and small trout sampled in Wyoming.

\section{Physical Habitat Stressors}

Riparian disturbance indicated more stream length was in a most-disturbed condition than either a least-disturbed or intermediate condition, both west-wide and in Wyoming (fig. 5A). The percentage of stream length in a most-disturbed condition was smallest in the mountains, at about 40 percent west-wide and 30 percent in Wyoming (fig. $5 B$ ), and largest in the xeric region, at about 80 percent west-wide and 90 percent in Wyoming (fig. 5C). Riparian disturbance in the plains (fig. $5 D$ ) was between that of the mountains and xeric regions.

Riparian vegetation measurements indicated 55 percent of the stream length west-wide was in a least-disturbed condition, whereas only 18 percent of the stream length in Wyoming was in a least-disturbed condition (fig. 5A). Percentages of stream length in a most-disturbed condition in the mountains (fig. $5 B$ ) in Wyoming and west-wide were similar although a greater percentage of stream length in Wyoming was in an intermediate condition and a smaller percentage was in a least-disturbed condition than west-wide. Riparian vegetation in the xeric (fig. $5 C$ ) and plains (fig. $5 D$ ) regions had larger percentages of most-disturbed stream length in Wyoming than west-wide.

Percentages of stream length in the three streamcondition categories for streambed stability in Wyoming were similar to percentages west-wide (fig. 5A). Mountain streams appear to be in better condition with respect to streambed stability in Wyoming, with 13 percent of the stream length in a most-disturbed condition, than west-wide, with about 22 percent in a most-disturbed condition (fig. $5 B$ ). In the xeric region (fig. $5 \mathrm{C}$ ), the percentages of stream length in each stream-condition category in Wyoming were similar to percentages west-wide; however, in Wyoming, the intermediate condition had the largest percentage of stream length at about 38 percent. The most-disturbed condition was predominant in the plains (fig. $5 D$ ).

Habitat complexity indicated 42 percent of the stream length in Wyoming was in a most-disturbed condition compared to 17 percent west-wide (fig. $5 \mathrm{~A}$ ). In the three climatic regions, the percentage of stream length having habitat complexity in a most-disturbed condition was larger in Wyoming than west-wide. In Wyoming, the mountains (fig. 5B) had a larger percentage of stream length in a least-disturbed condition than the xeric region (fig. $5 C$ ) or the plains (fig. $5 D$ ). 


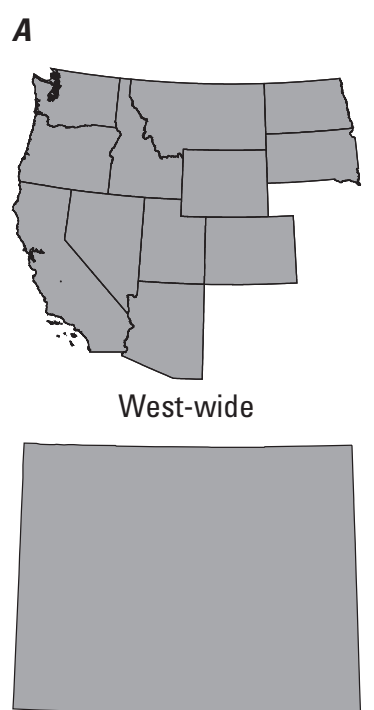

Wyoming

\section{Phosphorus}

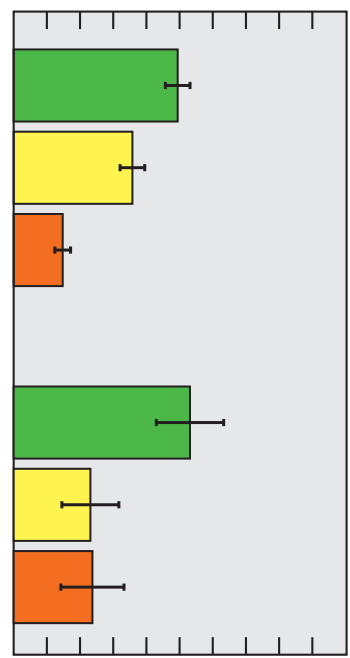

$0 \quad 10203040506070809010001020304050607080901000$
Nitrogen

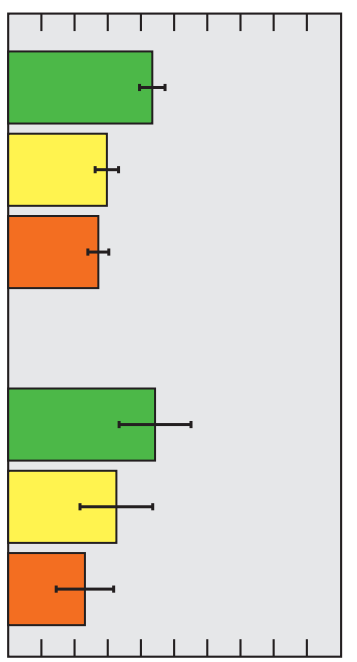

PERCENTAGE OF STREAM LENGTH IN REGION

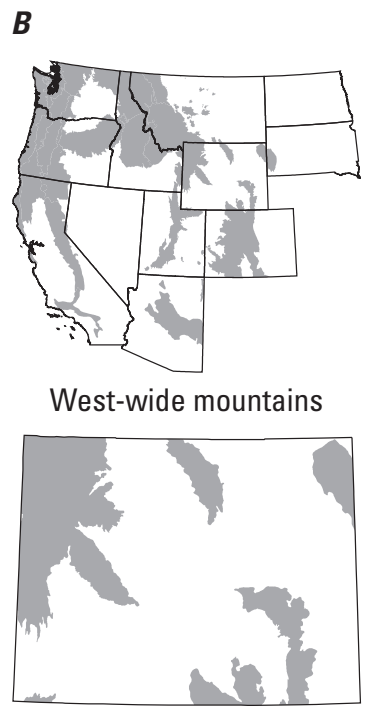

Wyoming mountains
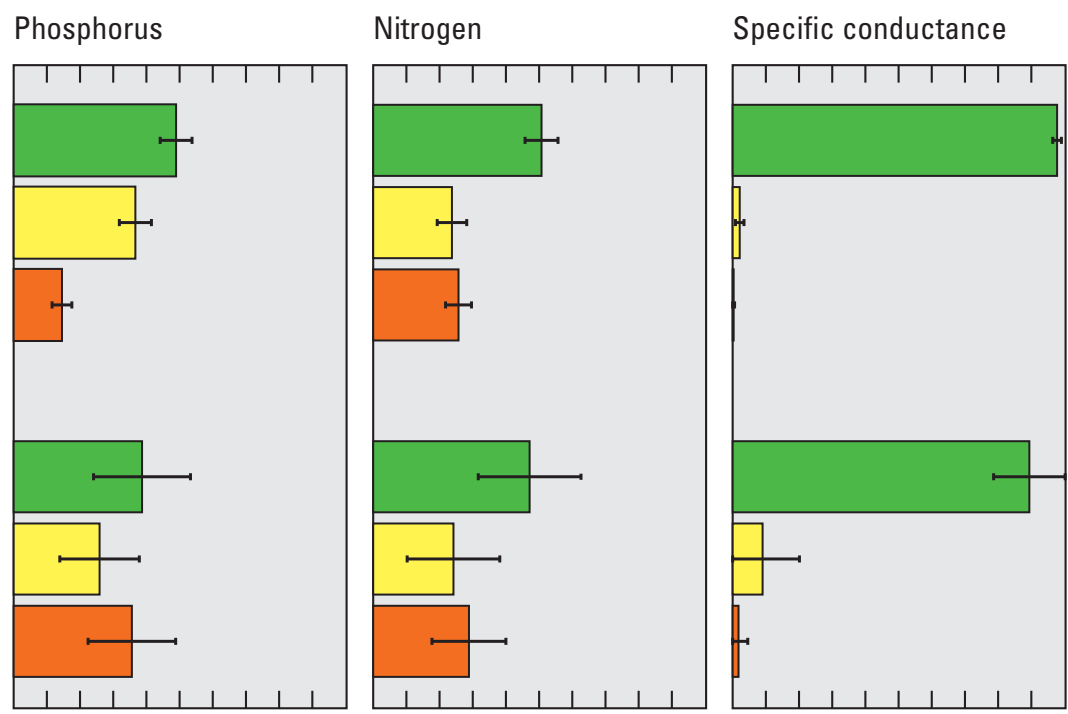

Mercury in fish

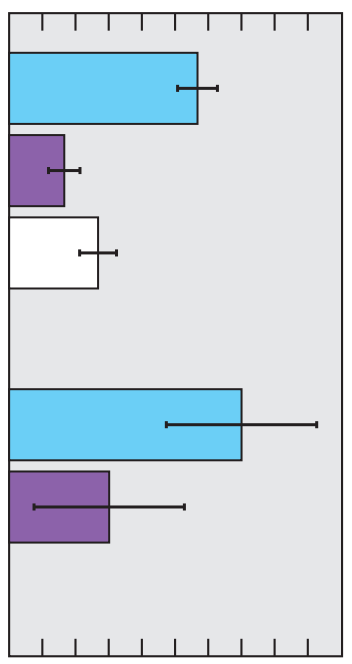

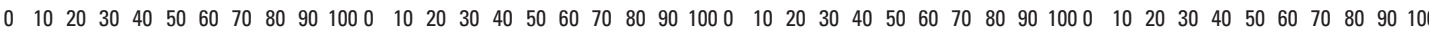

PERCENTAGE OF STREAM LENGTH IN REGION

\section{EXPLANATION}

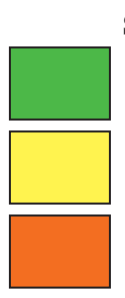

Stream condition category

Least disturbed

Intermediate

Most disturbed

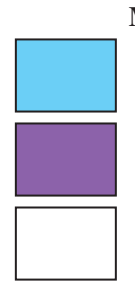

Mercury in fish

Less than 0.1 microgram per gram wet weight (least disturbed)

Greater than 0.1 microgram per gram wet weight (most disturbed)

No collection permit (stream length without fish-tissue data is not shown)

\section{5-percent confidence interval}

Figure 4. Summary of results for chemical stressors for Western Pilot Environmental Monitoring and Assessment Program study area, Wyoming, and three climatic regions. 


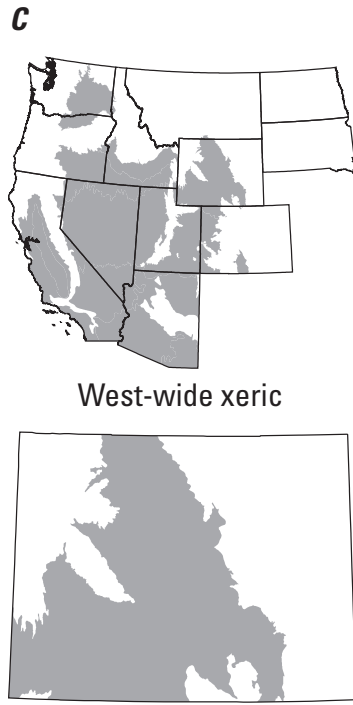

Wyoming xeric
Phosphorus

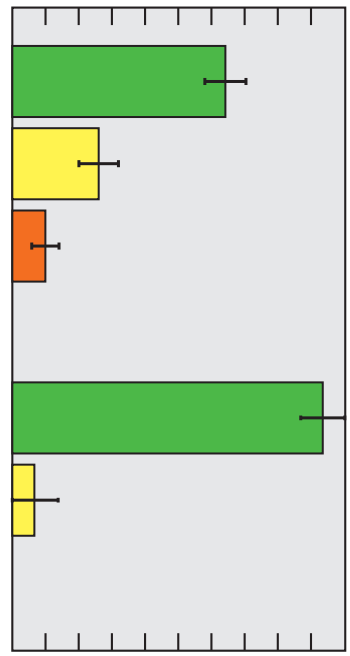

$0 \quad 102030405060708090100$
Nitrogen

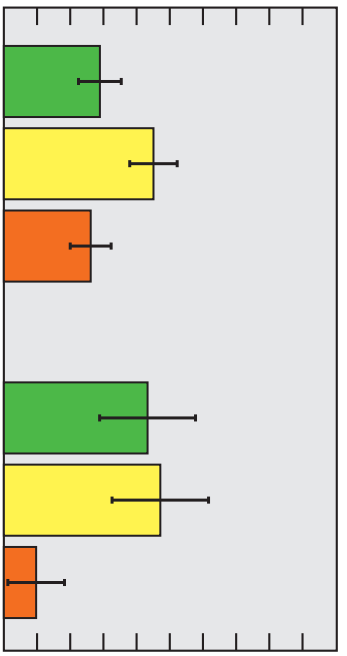

Specific conductance

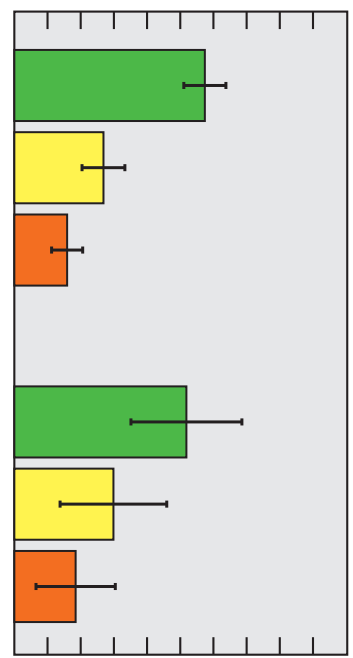

Mercury in fish

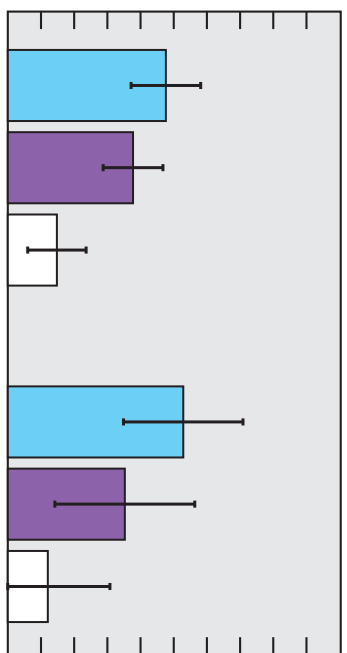

$1+1+1+1+1+1$ PERCENTAGE OF STREAM LENGTH IN REGION

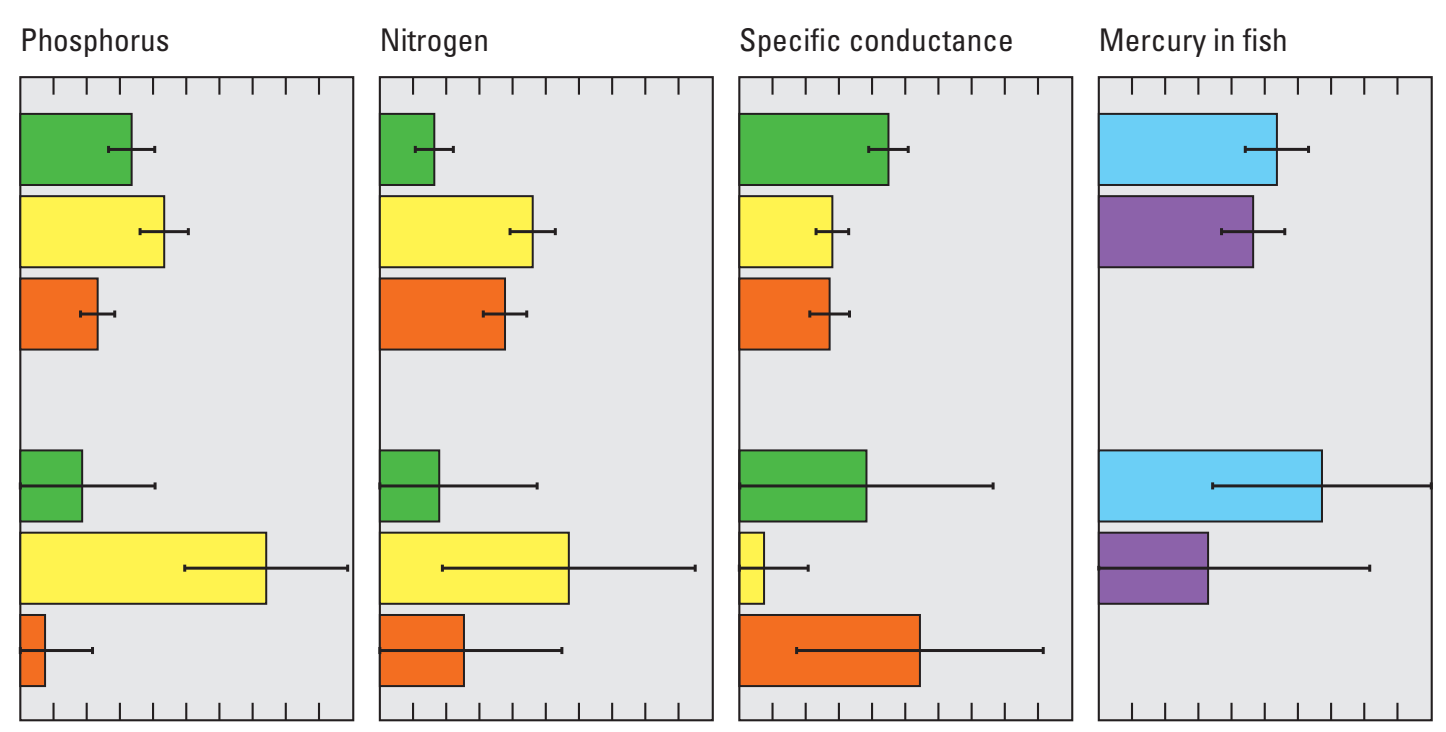

$01020304050 \quad 6070809010001020304050607080901000102030 \quad 40506070 \quad 80901000 \quad 10203040 \quad 5060 \quad 708090100$ PERCENTAGE OF STREAM LENGTH IN REGION
D

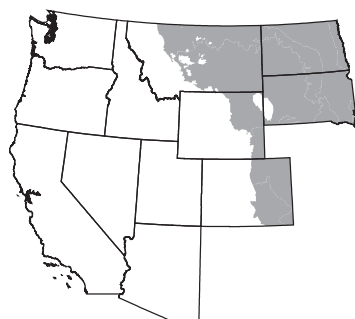

West-wide plains

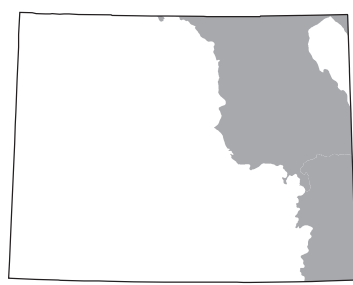

Wyoming plains

\section{EXPLANATION}

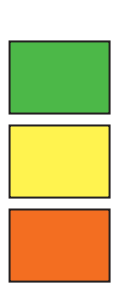

Stream condition category

Least disturbed

Intermediate

Most disturbed
Mercury in fish

Less than 0.1 microgram per gram wet weight (least disturbed)

Greater than 0.1 microgram per gram wet weight (most disturbed)

No collection permit (stream length without fish-tissue data is not shown)

\section{5-percent confidence interval}

Figure 4. Summary of results for chemical stressors for Western Pilot Environmental Monitoring and Assessment Program study area, Wyoming, and three climatic regions.-Continued 


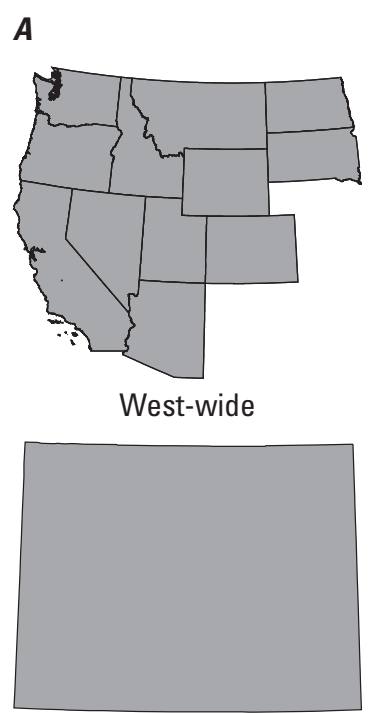

Wyoming

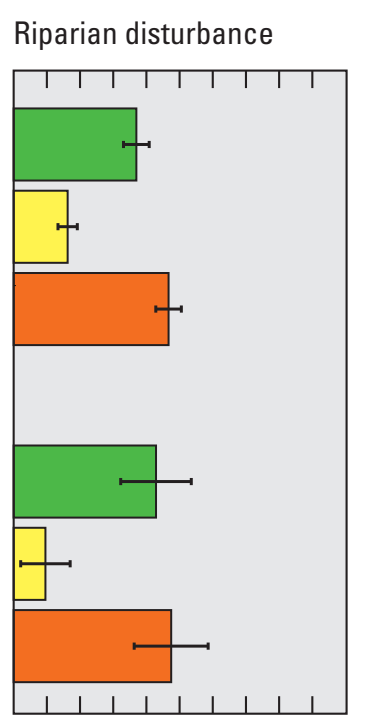

010203040506070809010001020304050607080901000

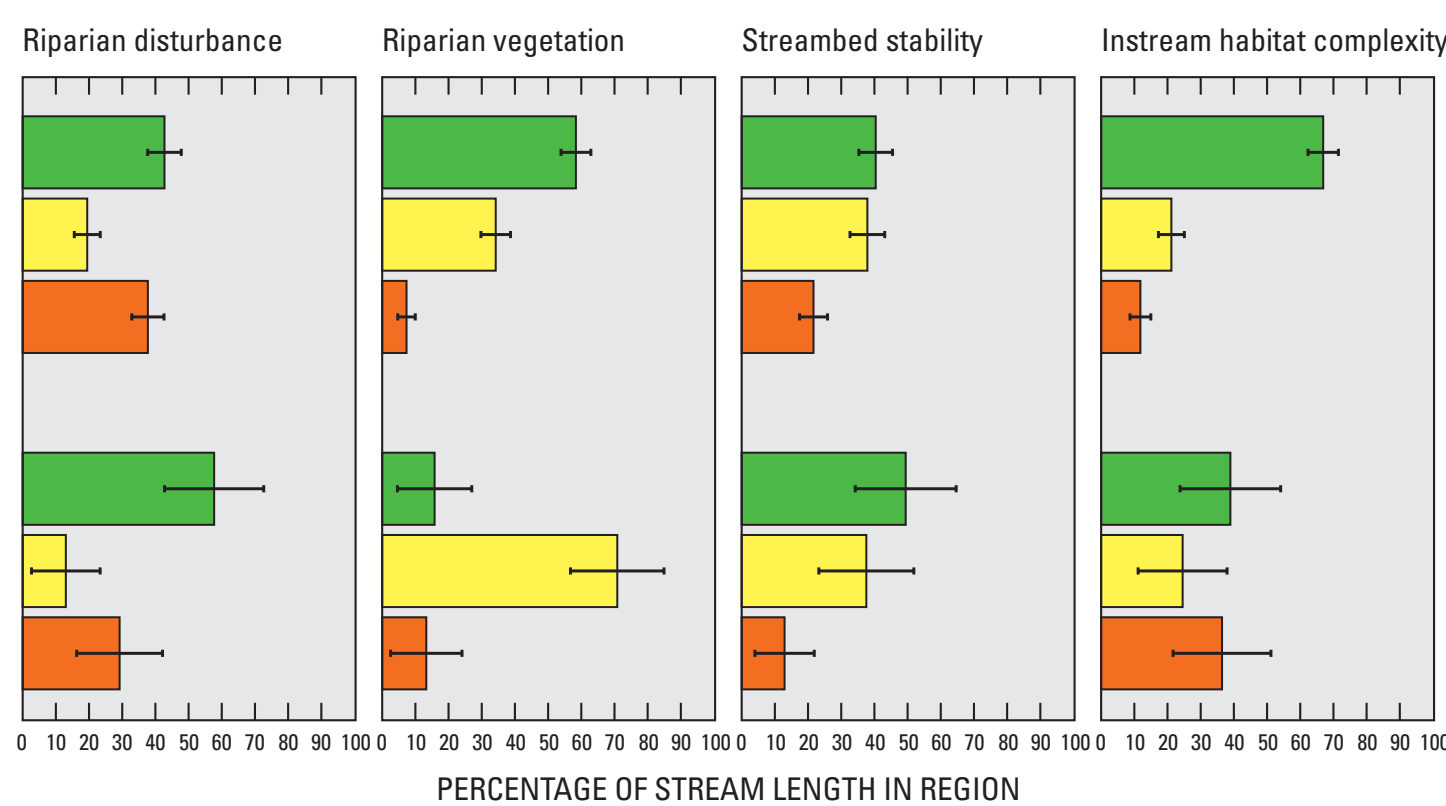

0102030405060708090100010203040506070809010001020304050607080901000102030405060708090100

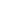

Streambed stability

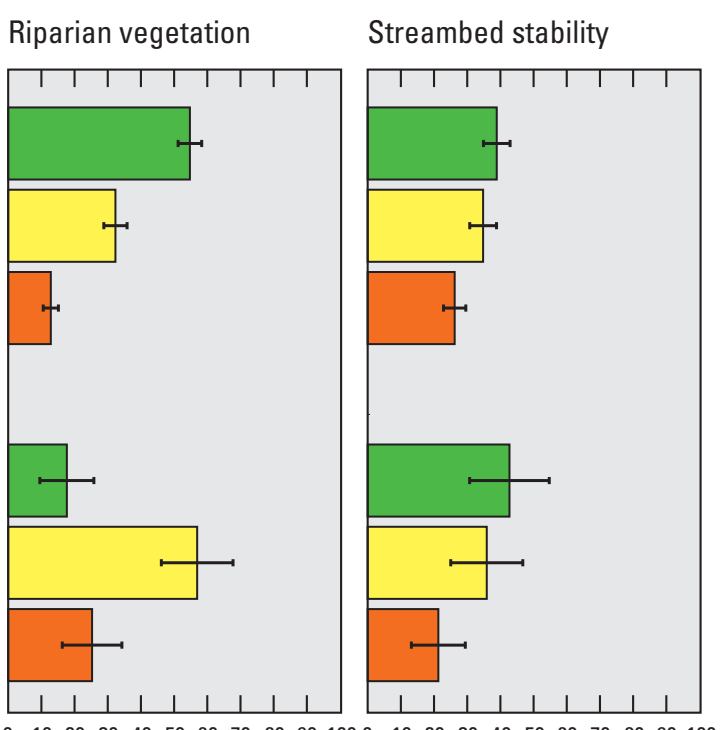

Instream habitat complexity

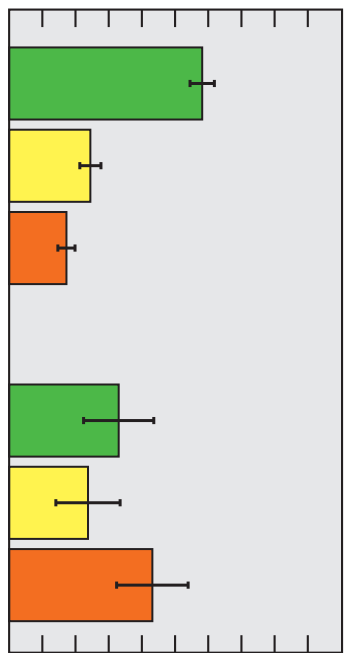

$\begin{array}{lllllllll}1 & 1 & 1 & 1 & 1 & 1 & 1 & 1 & 1\end{array}$ PERCENTAGE OF STREAM LENGTH IN REGION PERCENTAGE OF STREAM LENGTH IN REGION

nstream habitat complexity

EXPLANATION

Stream condition category

Least disturbed

Intermediate

Most disturbed

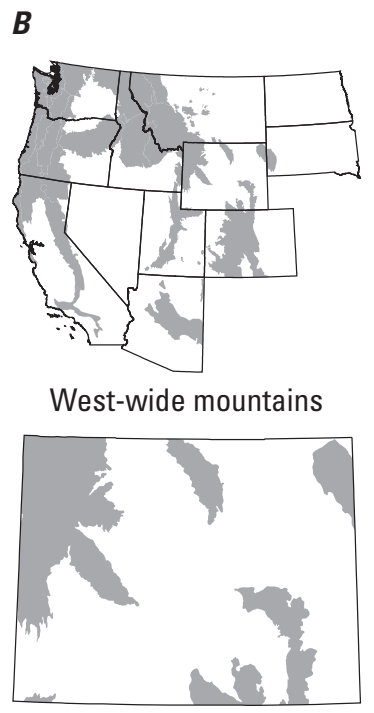

Wyoming mountains

Figure 5. Summary of results for physical habitat stressors for the Western Pilot Environmental Monitoring and Assessment Program study area, Wyoming, and three climatic regions. 


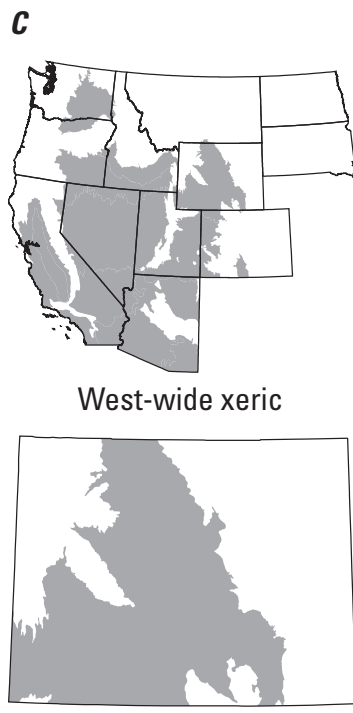

Wyoming xeric
Riparian disturbance

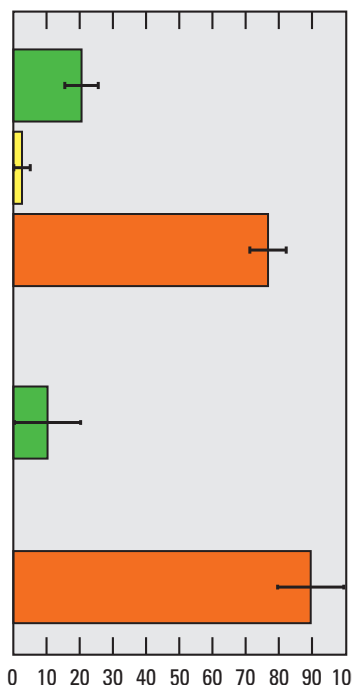

$0 \quad 102030405060708090100$
Riparian vegetation

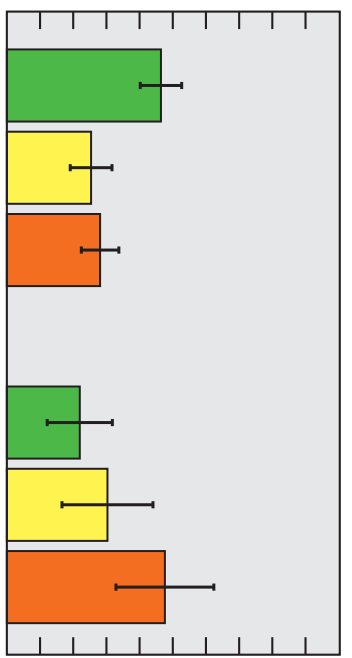

Streambed stability

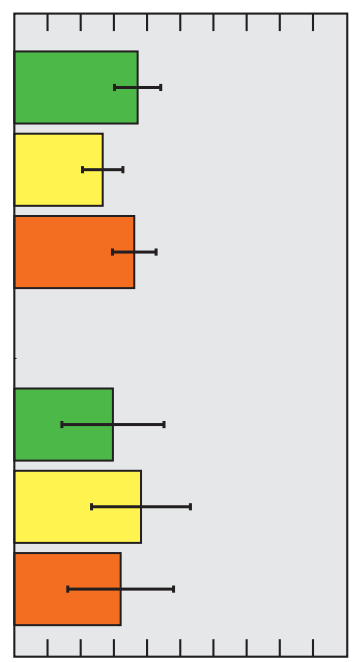

Instream habitat complexity

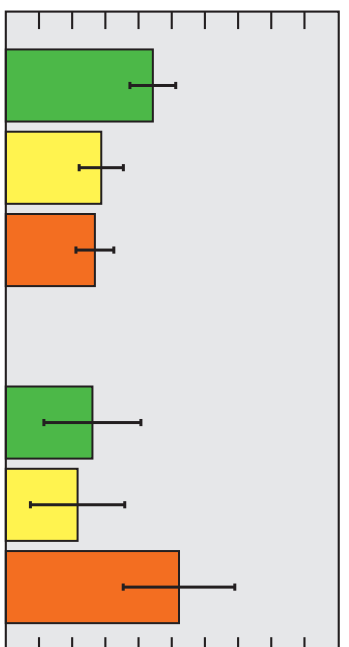

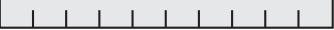
PERCENTAGE OF STREAM LENGTH IN REGION

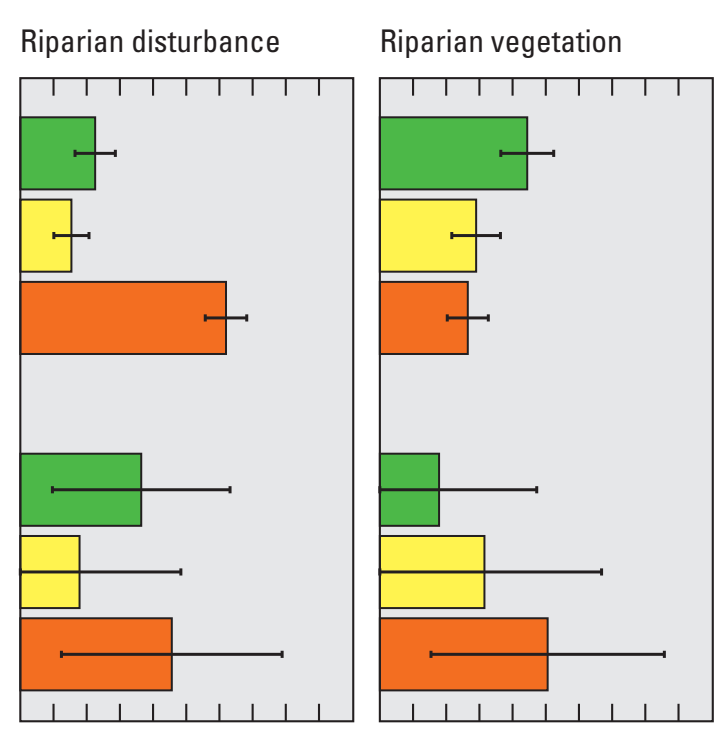

Streambed stability

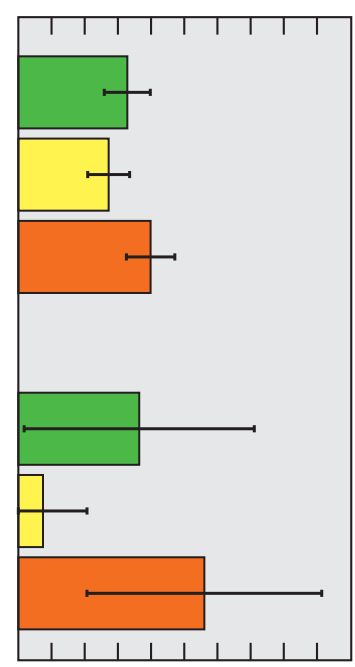

Instream habitat complexity

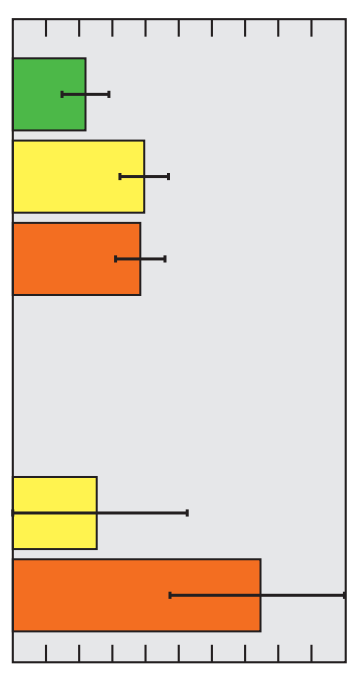

Wyoming plains $010203040506070809010001020304050607080901000102030 \quad 4050 \quad 6070 \quad 80901000 \quad 102030 \quad 40506070 \quad 8090100$ PERCENTAGE OF STREAM LENGTH IN REGION

\section{EXPLANATION}

Stream condition category

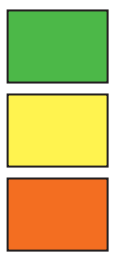

Least disturbed

Intermediate

Most disturbed

\section{ए5-percent confidence interval}

Figure 5. Summary of results for physical habitat stressors for the Western Pilot Environmental Monitoring and Assessment Program study area, Wyoming, and three climatic regions.-Continued 


\section{Biological Stressors}

EMAP samples indicated non-native vertebrates were common in many mountains and xeric region streams in Wyoming. Non-native vertebrates identified generally were trout, such as brown trout (Salmo trutta), brook trout (Salvelinus fontinalis), and rainbow trout (Oncorhynchus mykiss). Although these three trout species are not native to Wyoming, their presence likely reflects either stocking for recreational fishing or movement and reproduction from areas where they were stocked. Non-native trout can present a serious threat to genetic purity or existence of native cutthroat trout populations (Oncorhynchus clarki) (Koel and others, 2005), but that issue is beyond the scope of this report. Other non-native vertebrates identified include common carp (Cyprinus carpio) and the fathead minnow (Pimephales promelas), which has been introduced to Wyoming west of the continental divide.

The Asian clam (Corbicula fluminea) and some nonnative species of crayfish (Decapoda) were noted as invertebrate biological stressors to streams in the southwestern United States by Stoddard and others (2005b). Those species of invertebrates were absent or not identified in EMAP samples from Wyoming. The New Zealand mud snail, an exotic that can substantially alter stream invertebrate communities and nutrient cycling, has been documented in northwestern Wyoming (Hall and others, 2003) but was not noted in EMAP samples from Wyoming.

\section{Relative Extent of Stressors}

For each stressor indicator, the percentage of stream length in a most-disturbed condition was used to provide information on which stressors are most extensively affecting stream resources. Riparian disturbance was the most common stressor to streams west-wide and in all three climatic regions across the West (mountains, xeric, and plains; fig. 6). Riparian disturbance also was a common stressor to streams statewide and in the climatic regions in Wyoming but was the predominant stressor only in the xeric region in Wyoming where about 90 percent of the stream length was rated in poor condition as a result of riparian disturbance. Other physical stressors that affected Wyoming streams were (1) a lack of habitat complexity that affected more than 40 percent of the stream length statewide; (2) riparian vegetation that was rated poor in more than 40 percent of the stream length in the xeric and plains regions; and (3) streambed stability that affected more than 50 percent of the stream length in the plains. Nitrogen and phosphorus, which are chemical stressors, affected about 20 percent of the stream length statewide; phosphorus affected 36 percent of the stream length in the Wyoming mountains. Specific conductance affected less than 10 percent of the stream length statewide but more than 50 percent of the stream length in the plains. Non-native vertebrates were common in Wyoming, except in the plains, but this stressor was affected by introduced game fish as previously described.

\section{Assessment of Aquatic Life Use Support Using Wyoming Framework}

This section of the report presents an analysis of EMAPWest data from Wyoming using water-quality criteria and macroinvertebrate data analysis techniques developed by the State of Wyoming. As described in the following sections, results from the Wyoming MMI, which is known as the Wyoming Stream Integrity Index (WSII), and the Wyoming $\mathrm{O} / \mathrm{E}$ index are synthesized into the ALU decision matrix. The analysis provides a water-quality evaluation and ALU support designations for Wyoming streams using a probability based data set.

To maximize compatibility of EMAP-West data with Wyoming data analysis techniques, data from three nonwadeable sites were excluded from the analysis. The location and other selected characteristics of the 71 EMAP sampling sites used in the analysis are given in appendixes 1 and 2.

\section{Water Quality}

Numeric aquatic life criteria exist for three of the waterquality constituents for which EMAP samples were analyzed. Criteria for total chloride, dissolved zinc, and $\mathrm{pH}$ are listed in appendix B of chapter 1 of the Wyoming Water Quality Rules and Regulations (Wyoming Department of Environmental Quality, 2001).

Chloride concentrations exceeded the aquatic life chronic value of 230 milligrams per liter $(\mathrm{mg} / \mathrm{L})$ in 3 percent of the stream length in Wyoming. By climatic region, the chronic value for chloride was not exceeded in the mountains but was exceeded in 4 percent of the stream length in the xeric region and 36 percent of the stream length in the plains. The acute aquatic life value of $860 \mathrm{mg} / \mathrm{L}$ for chloride was not exceeded in the mountains and xeric regions but was exceeded in 18 percent of the stream length in the plains. The hardnessdependent chronic aquatic life criterion for dissolved zinc was exceeded in 3 percent of the stream length in the mountains but was not exceeded in the xeric and plains regions. All of the $\mathrm{pH}$ values were within the acceptable chronic ALU criterion range of 6.5 to 9.0 standard units.

\section{Macroinvertebrates}

Wyoming's biological indicators (WSII and O/E index) were used in conjunction with the MMI and O/E indicators developed by the USEPA for the western States to assess the biological condition of EMAP sampling sites located in Wyoming. The macroinvertebrate-based multi-metric WSII and the Wyoming O/E index used by the WDEQ to assess the biological condition of a wadeable stream are similar to the EMAP macroinvertebrate MMI and O/E indices with respect to index development and structure. 


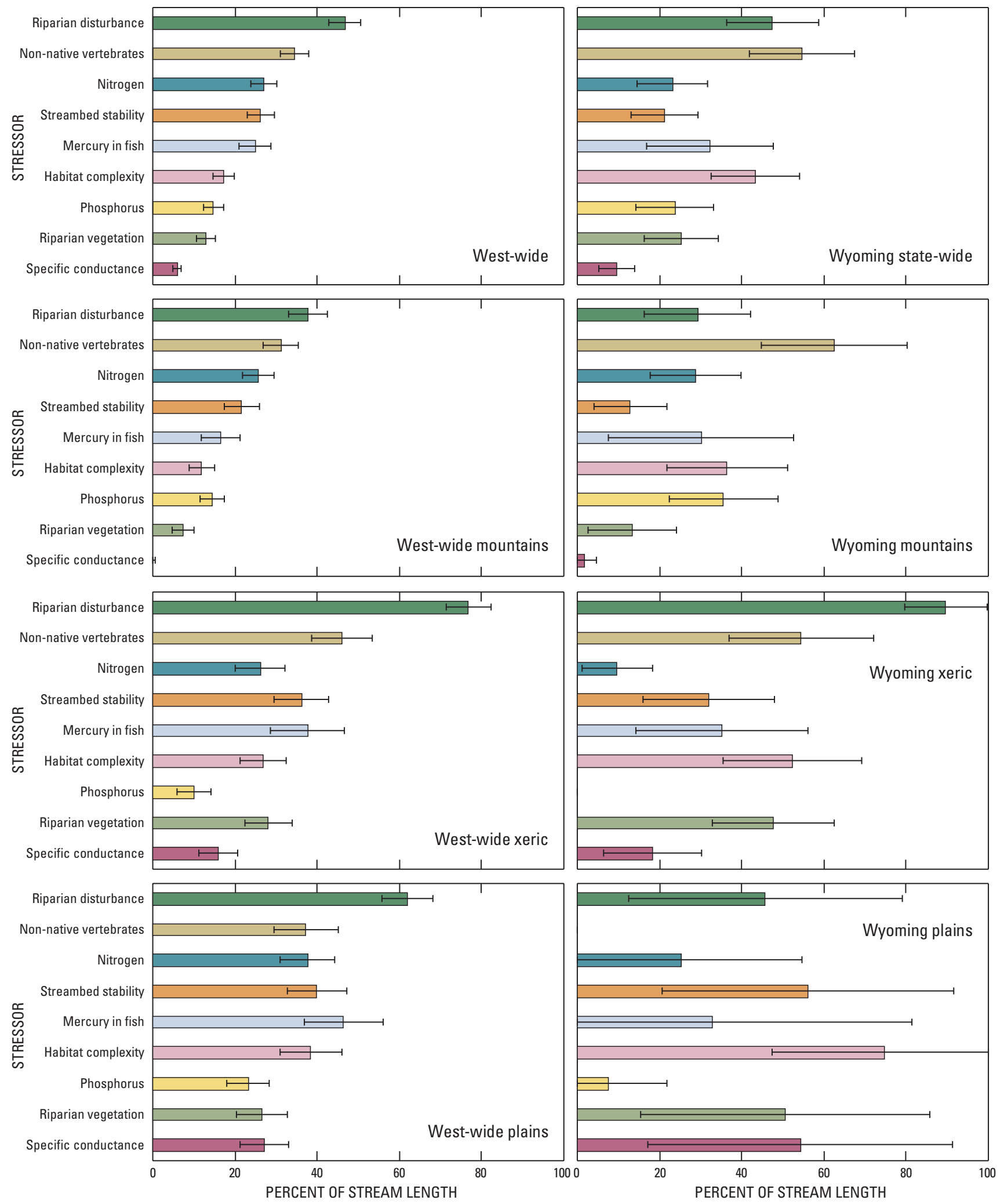

EXPLANATION

$\longmapsto 95$-percent confidence interval

Figure 6. Relative extent of chemical, physical, and biological stressors indicating most-disturbed condition for the Western Pilot Environmental Monitoring and Assessment Program study area, Wyoming, and three climatic regions. (Data for Asian clam and nonnative crayfish are not shown because those species were not identified in samples from Wyoming and occurred in 2 percent of the stream length West-wide.) 


\section{Wyoming Stream Integrity Index Methodology}

The design concept of the WSII parallels that of EMAP's west-wide macroinvertebrate MMI in that the WSII is a regionally calibrated macroinvertebrate-based MMI designed to assess ALU support in perennial streams in Wyoming (Hargett and Zumberge, 2006). The WSII technically is an aggregation of seven individual indices developed for seven bioregions delineated within Wyoming. Core macroinvertebrate metrics (for example, composition, structure, tolerance, and functional guilds) with moderate to high discrimination efficiencies (degree of separation between metric values of reference and degraded sites) within and across bioregions, a relatively consistent mode of response to human disturbance across bioregions, and no redundancy with other metrics were incorporated into the WSII. Scoring of individual metric values was based on comparisons to the 5th and 95th percentiles of bioregional reference conditions for each metric. The final index score is an average of the individual metric scores, and a large final score implies a good biological condition. Based on unique numeric thresholds derived from the 25th percentile of reference conditions for each bioregion and an equal trisection of values below this threshold, index scores were codified into one of two narrative ALU support categories (full support and partial/non-support), or an indeterminate category that technically is a designation that requires the use of other information to make a proper use-support assignment. Details on the numeric thresholds for each bioregion and more information on the WSII are given in Hargett and Zumberge (2006).

\section{Wyoming Observed/Expected Index Methodology}

Similar to the west-wide EMAP O/E index, the Wyoming $\mathrm{O} / \mathrm{E}$ index is a statewide macroinvertebrate-based predictive model that provides an assessment of biological condition by comparing the macroinvertebrate taxa observed at a site of unknown biological condition to the indigenous macroinvertebrate taxa expected to occur in the absence of human stress (Hargett and others, 2005; Hargett and others, in press). Predictor variables, such as site latitude, site longitude, substrate type, watershed area, elevation, and geology, were used to construct the model. The expected macroinvertebrate taxa were derived from an appropriate set of reference sites that were minimally or least affected by anthropogenic stress. The deviation of the observed from the expected taxa, known as the $\mathrm{O} / \mathrm{E}$ index, is a measure of the compositional similarity expressed in units of taxa richness and, thus, is a community level measure of biological condition. O/E values near 1 imply a good biological condition, whereas $\mathrm{O} / \mathrm{E}$ values of less than 1 imply some degree of biological degradation as a result of loss of expected taxa. $\mathrm{O} / \mathrm{E}$ values are codified into two narrative ALU support criteria or an indeterminate category where values greater than 0.836 were considered full support, values between 0.836 and 0.662 were considered indeterminate, and values less than 0.662 were considered partial/non-support. The numeric full-support threshold was based on 1 standard deviation from the mean $\mathrm{O} / \mathrm{E}$ value of the reference samples, whereas the indeterminate and partial/non-support thresholds were based on 2 standard deviations from the mean O/E value of the reference samples.

The Wyoming and EMAP multimetric and O/E models may have differences in accuracy and precision because of the use of regional rather than State macroinvertebrate faunas, taxonomic resolution, metric selection, predictive variables, and reference criteria. However, the concepts and development of the Wyoming and EMAP models closely parallel one another so that valid general comparisons between the Wyoming and EMAP methods can be made to assess the biological condition of benthic macroinvertebrates in Wyoming. The Wyoming and EMAP attainment categories are similar in that Wyoming's full-support condition is approximately equivalent to EMAP's least-disturbed condition where a stream is supportive of a macroinvertebrate community that is similar to reference expectations. In addition, Wyoming's partial/non-support condition is similar to EMAP's most-disturbed condition where a stream's macroinvertebrate community has been compromised by anthropogenic stressors and the condition deviates substantially from reference expectations. Lastly, Wyoming's indeterminate and EMAP's intermediate categories both describe streams that have biological conditions somewhere between the fullsupport and partial/non-support categories, indicating some deviation from reference expectations.

\section{Compatibility of West-Wide Data with Wyoming Models}

Two types of macroinvertebrate samples were collected during the west-wide study: (1) targeted riffle samples, and (2) transect-based, reachwide samples. The EMAP riffle sample was a composite of eight samples, each from an area of 0.0929 square meter $\left(\mathrm{m}^{2}\right)$ for a total area of $0.74 \mathrm{~m}^{2}$, collected from random locations in riffles throughout the stream reach. The EMAP reachwide sample was a composite of 11 samples, each from an area of $0.0929-\mathrm{m}^{2}$ for a total area of $1.02 \mathrm{~m}^{2}$, collected from multiple habitats by selecting one random location at each of 11 transects spaced evenly throughout the sample reach. The methods used to collect the EMAP targeted riffle sample are similar to the methods used by the WDEQ to collect macroinvertebrate samples. The WDEQ riffle sample was a composite of eight samples, each from an area of $0.0929 \mathrm{~m}^{2}$ for a total area of $0.74 \mathrm{~m}^{2}$, collected randomly from riffle habitat (Wyoming Department of Environmental Quality, 1999); both methods specify a 500-micron mesh sampling net. Data from the WDEQ riffle samples were used by the WDEQ to develop the WSII and the Wyoming O/E index described previously; therefore, the EMAP riffle samples theoretically are more suitable than the reachwide samples for analysis 
using the Wyoming WSII and O/E index. The limitation to this approach is the lack of riffles at 14 of the 71 EMAP sampling sites in Wyoming where the reachwide macroinvertebrate sample was the only sample collected. The sites that have only reachwide samples represent about 21 percent of the stream length in Wyoming.

Although the Wyoming O/E index is tailored specifically to evaluate only riffle-based macroinvertebrate samples, reachwide samples possibly could be evaluated with the WSII where targeted riffle data are not available. To address this issue, macroinvertebrate metrics and corresponding WSII scores from reachwide samples were compared to those from targeted riffle samples. Metrics and WSII scores from a total of 64 paired reachwide and targeted riffle samples (including quality-control samples from three sites) from across Wyoming were categorized according to climatic region and tested for correlation. Because of the small number of paired samples in the plains and the possibility for statistical errors when evaluated separately, the samples from the plains were combined with paired samples from the xeric region before the correlation analysis. Pooling the paired samples from the plains and xeric regions was further justified by the general similarities in ecological conditions and macroinvertebrate community structure. The correlation coefficients (table 2) generally were within the range of 0.70 to 0.90 , indicating acceptable agreement between the sample types, particularly with respect to WSII scores. Therefore, the decision was made to evaluate reachwide samples with the WSII when riffle samples were not available. This decision is supported by recent applications of this approach by Gerth and others (2006) and Rehn and others (2007). Conclusions from their studies indicated that typical biological indicators, such as $\mathrm{MMI}$ and $\mathrm{O} / \mathrm{E}$ indices, are robust in the evaluation of biological condition with respect to sample type for regional surveys. Furthermore, targeted riffle and reachwide samples provide similar estimates of biological condition when evaluated at a regional scale.

\section{Wyoming Stream Integrity Index Biological Condition}

On a statewide scale, the WSII assessed 41 percent of Wyoming's stream length as being in the full-support condition with lesser percentages being either in the indeterminate or partial/non-support condition (fig. 7). The xeric region had a larger percentage of stream length (46 percent) in the full-support condition than the mountains (39 percent). Of the three climatic regions, the mountains had the largest percentage of stream length (34 percent) in the partial/non-support condition, followed by the xeric region ( 24 percent). About 54 percent of the stream length in the plains was assessed as being in the indeterminate condition; however, data for that region should be viewed with caution because of the small number of samples (seven) available for analysis. In general, the WSII assessment of biotic condition on both the statewide and climatic region levels was similar to that derived from the EMAP macroinvertebrate MMI. One exception was that the WSII assessed a larger percentage of mountain stream length ( 34 percent) as being in the partial/non-support (most-disturbed) condition than did the EMAP macroinvertebrate MMI (20 percent). Another area of difference was in the assessment of plains streams, but the differences for those streams might be affected by the small number of sampling sites in the plains of Wyoming and by the small percentage of EMAP plains reference sites that were located in Wyoming compared to the percentage located in Montana and in North and South Dakota.

\section{Wyoming Observed/Expected Index Biological Condition}

The Wyoming O/E index assigned a statewide biological condition similar to that assigned by the WSII. Statewide, 43 percent of Wyoming's stream length was considered to be in the full-support condition and nearly identical percentages (approximately 29 percent) were considered to be in the indeterminate and partial/non-support categories (fig. 7). The mountains and xeric regions had nearly the same percentages of stream length (about 45 percent) in the full-support condition as statewide. The percentage of stream length in the partial/non-support condition was larger in the mountains (31 percent) than in the xeric region (11 percent). The plains had only three sampling sites suitable for the Wyoming O/E index analysis; therefore, those sites were included in the statewide analysis (fig. 7) but are not discussed separately because of the issues, as previously noted, associated with an insufficient sample size. Overall, the Wyoming O/E index assigned regional biological conditions similar to those of the WSII.

Comparison of the results from the EMAP O/E index to the Wyoming macroinvertebrate $\mathrm{O} / \mathrm{E}$ index indicated some similarities and some differences. On a statewide scale, the EMAP macroinvertebrate $\mathrm{O} / \mathrm{E}$ index assigned 26 percent of the stream length to a most-disturbed condition; that percentage was similar to that assigned by the Wyoming O/E index (partial/non-support, 28 percent). A greater percentage of stream length at the statewide scale (58 percent) was considered least disturbed by the EMAP O/E index, however, compared to the 43 percent assigned to the full-support condition by the Wyoming O/E index. Furthermore, a greater percentage of stream length in the mountains was considered least disturbed by the EMAP O/E index than by the Wyoming $\mathrm{O} / \mathrm{E}$ index. In the xeric region, 43 percent of the stream length was considered least disturbed by the EMAP O/E index; that percentage is similar to the 46 percent assigned to the fullsupport condition by the Wyoming $\mathrm{O} / \mathrm{E}$ index. In general, the EMAP O/E index assigned a smaller percentage of stream length at the climatic regional scales to the most-disturbed condition than that assigned to the partial/non-support condition by the Wyoming $\mathrm{O} / \mathrm{E}$ index. 


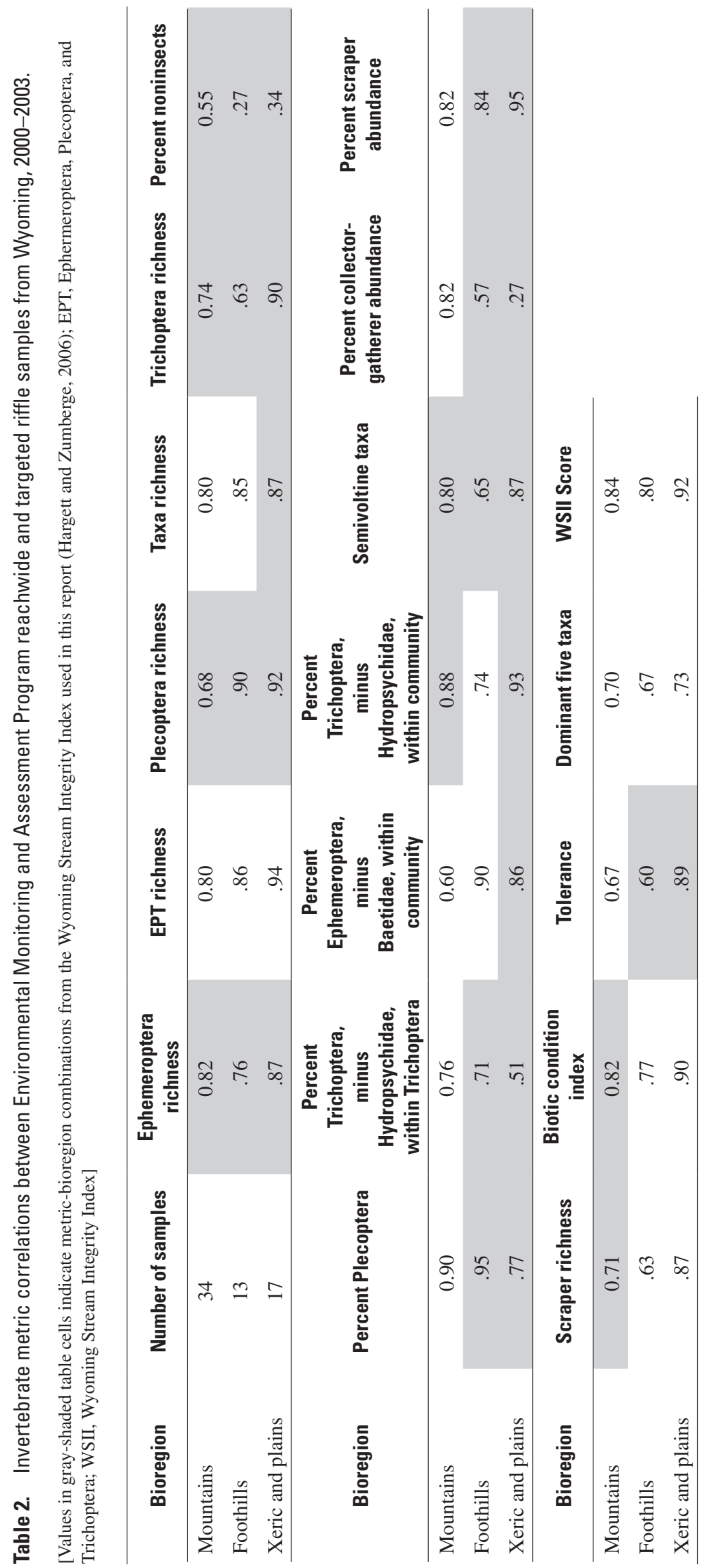


Wyoming Stream Integrity Index
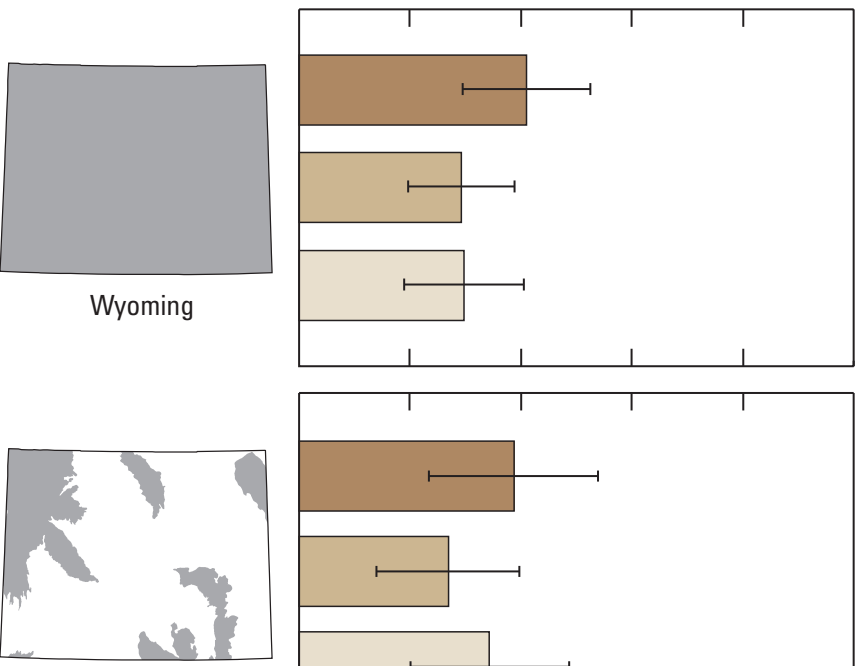

Wyoming mountains
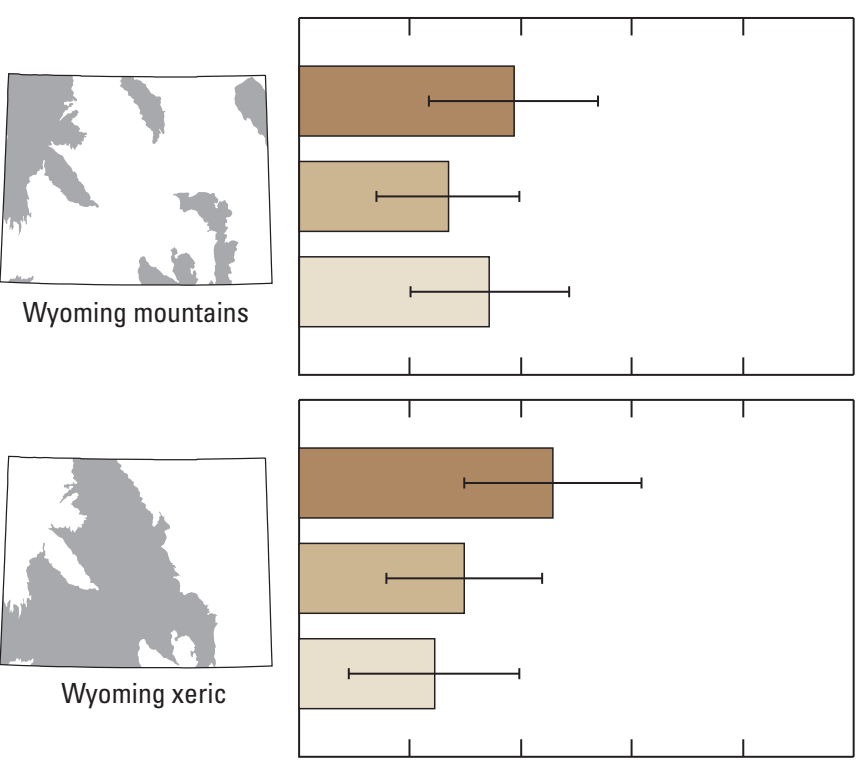

Wyoming xeric

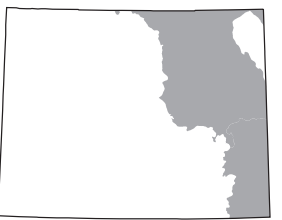

Wyoming plains

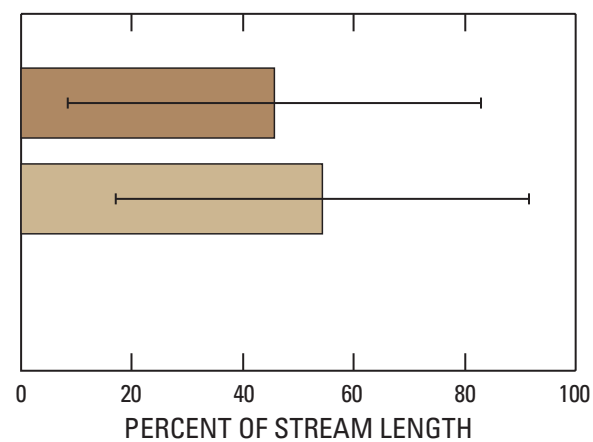

\section{EXPLANATION}

Full support

Indeterminate

Partial/non-support

95-percent confidence interval

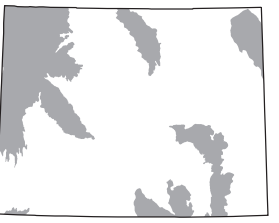

Wyoming mountains

Wyoming Observed/Expected

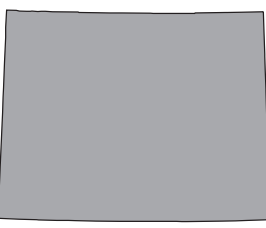

Wyoming
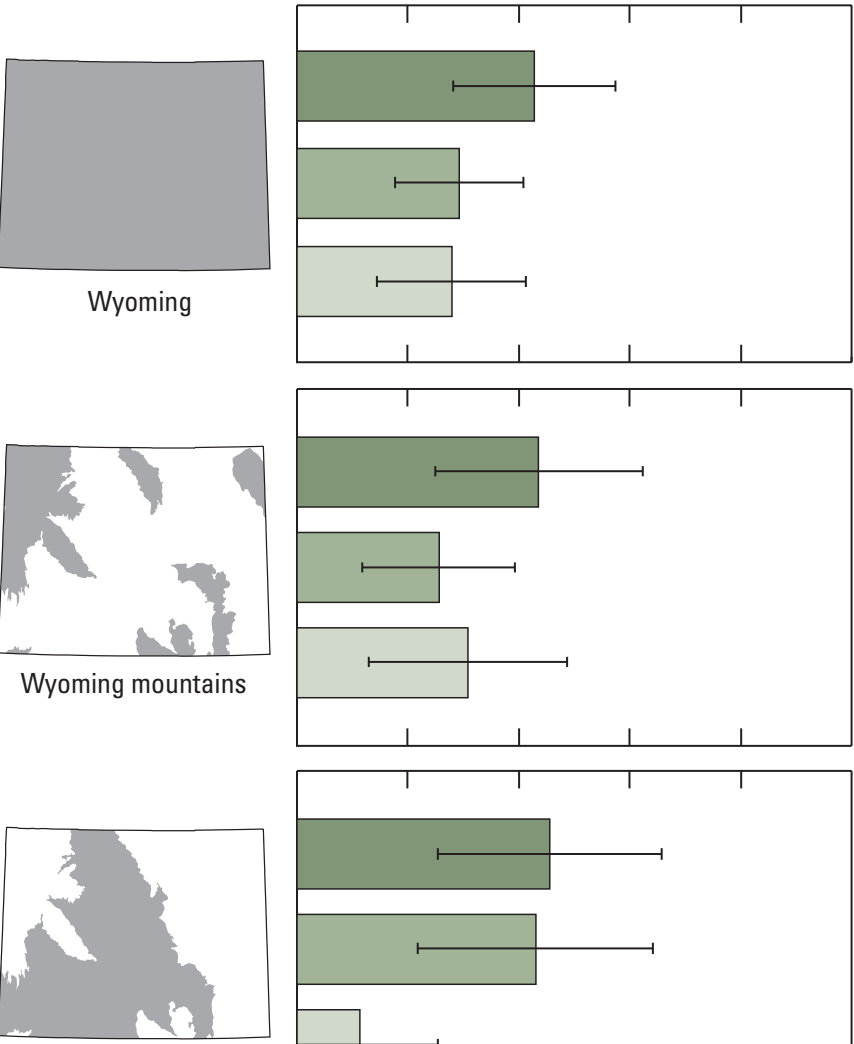

Wyoming xeric

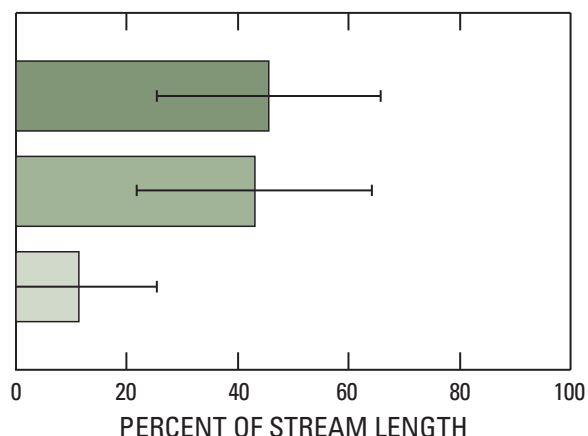

EXPLANATION

Full support

Indeterminate

Partial/non-support

95-percent confidence interval

Figure 7. Condition of streams in Wyoming, as indicated by the Wyoming Stream Integrity Index and the Wyoming observed/expected index. (The observed/expected data are not shown for the plains climatic region because of an insufficient number of samples.) 


\section{Wyoming Aquatic Life Use Support Decision Matrix}

The results calculated by the WSII and Wyoming $\mathrm{O} / \mathrm{E}$ index models were treated as biological water-quality parameters. These parameters were evaluated to determine whether the narrative ALU criterion in chapter 1 of the Wyoming Water Quality Rules and Regulations (Wyoming Department of Environmental Quality, 2001) was attained as outlined in table 3 . Sites that achieved the narrative criterion were assessed as fully supporting ALU. Sites that exceed the narrative criterion were assessed as either partially or not supporting ALU, depending on the strength of the supporting physical and chemical data. For purposes of this report, partial and non-support were combined into one category. Sites characterized as undetermined by this matrix did not receive an assessment of ALU support and are considered in need of further investigation.

Using the ALU matrix, biological condition on a statewide and climatic regional scale generally followed a pattern similar to that derived from the WSII, Wyoming O/E index, EMAP macroinvertebrate MMI, and EMAP macroinvertebrate $\mathrm{O} / \mathrm{E}$ index. Statewide, the ALU matrix indicated 52 percent of the stream length in Wyoming achieves the State's narrative ALU criteria, 16 percent is undetermined, and 32 percent exceeds the State's narrative ALU criteria (fig. 8). The xeric region had a larger percentage of stream length (66 percent) that achieved Wyoming's narrative ALU criteria than the mountains (51 percent). About 26 percent of the stream length in the xeric region and 33 percent in the mountains exceeded the State's narrative ALU criteria, indicating partial or nonsupport of aquatic life uses.

Despite fundamental differences between the Wyoming and EMAP models and differing biogeographic factors within
Wyoming, the general similarity in biological condition of Wyoming streams derived from these models is encouraging in that the models are detecting similar degrees of anthropogenic disturbance and accounting for differences in macroinvertebrate assemblages. However, differences in the development of the Wyoming and EMAP models, including but not limited to model reference expectations, taxonomic resolution, and site stratification, translate into differences in biological condition assessments within some regions of Wyoming. An important aspect of use of the WSII and Wyoming O/E index models for assessment of biological condition is that these analytical tools were tailored specifically for use in Wyoming to determine attainment of the State's narrative ALU criteria.

\section{Future Directions}

The WDEQ, which implemented a probability survey into its monitoring strategy in 2004, has sampled 15 to 20 sites per year and will continue to do so for the foreseeable future (Zumberge, 2004). The WDEQ design builds upon the foundation laid by EMAP to enhance the State's ability to assess and track water-quality conditions at large spatial scales without the need for a complete census of stream sites. In addition, probability surveys present an unbiased method for locating problem areas in need of water-quality improvement and an additional means of finding new candidate reference sites. Wyoming's current probability survey design could be modified so that more sites in the plains are selected and assessed. Because plains streams represent a relatively small percentage of the total stream length in Wyoming, it is unlikely that an adequate number of sites will be selected to support assessment of the plains streams without modification of the design.

Table 3. Wyoming aquatic life use criteria, as determined by the Wyoming Stream Integrity Index and observed/expected index narrative categories.

[WSII, Wyoming Stream Integrity Index; O/E, observed/expected]

\begin{tabular}{|c|c|c|c|c|}
\hline & & \multicolumn{3}{|c|}{ Wyoming $0 / E$ narrative category } \\
\hline \multirow[b]{3}{*}{ WSII narrative category } & & Full support & Indeterminate & Partial/non-support \\
\hline & Full support & $\begin{array}{c}\text { Achieves narrative aquatic } \\
\text { life use criteria }\end{array}$ & $\begin{array}{c}\text { Achieves narrative aquatic } \\
\text { life use criteria }\end{array}$ & Undetermined \\
\hline & Indeterminate & $\begin{array}{c}\text { Achieves narrative aquatic } \\
\text { life use criteria }\end{array}$ & Undetermined & $\begin{array}{c}\text { Exceeds narrative aquatic } \\
\text { life use criteria }\end{array}$ \\
\hline
\end{tabular}




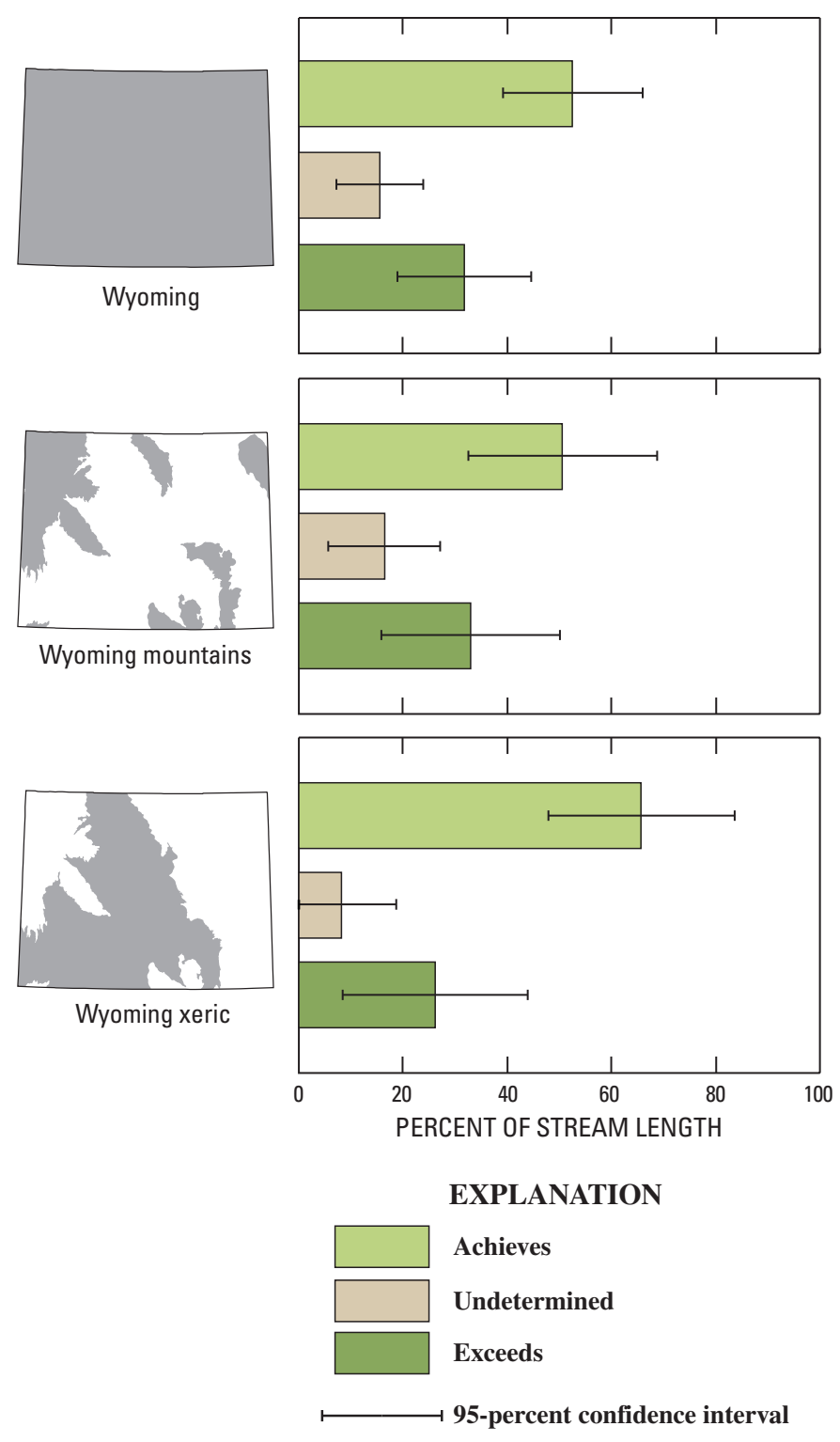

Figure 8. Aquatic life use attainment of streams in Wyoming, as indicated by a matrix of narrative criteria from the Wyoming Stream Integrity Index and the observed/expected index.

\section{Summary and Conclusions}

Environmental Monitoring and Assessment Program (EMAP) data were collected from 74 sites in Wyoming, using a probability based design to select stream reaches from the U.S. Environmental Protection Agency's River Reach File 3. An ecological assessment of data for ecological indicators, chemical stressors, and physical stressors was conducted by the U.S. Geological Survey, in cooperation with the Wyoming Department of Environmental Quality, by comparing data from sampling sites to reference conditions established for 12 western States that participated in the Western Pilot EMAP study (west-wide). Data from Wyoming were compared to the west-wide results and by climatic region-mountains, xeric, and plains. Ecological condition categories_least disturbed, most disturbed, and intermediate-were determined from reference conditions identified for each of the climatic regions. Major findings of the ecological assessment were:

- Ecological indicators, which are biotic integrity of aquatic vertebrate communities as measured by a multi-metric index (MMI), biotic integrity of macroinvertebrate communities as measured by an MMI, and a macroinvertebrate observed/expected $(\mathrm{O} / \mathrm{E})$ index, generally indicated conditions in Wyoming were similar to conditions observed west-wide. Most of the stream length in the mountains climatic region was in a least-disturbed condition, both in Wyoming and westwide, for all three ecological indicators. An exception was the macroinvertebrate MMI for Wyoming that indicated a larger percentage of stream length in the mountain climatic region was in an intermediate condition than least-disturbed or most-disturbed condition. The xeric and plains climatic regions, both west-wide and in Wyoming, tended to have a larger percentage of stream length in a most-disturbed or intermediate condition than the mountain region, relative to their respective reference conditions.

- Chemical stressors indicated conditions within Wyoming generally were similar to those west-wide. The least-disturbed condition prevailed statewide and west-wide, where phosphorus and nitrogen concentrations were least disturbed for about 40 to 50 percent of the stream length, and specific conductance values were least disturbed for about 80 percent of the stream length. Mercury concentrations in fish were less than the criterion for protection of piscivores (leastdisturbed condition) in about 63 percent of stream length in Wyoming and 54 percent west-wide.

- Physical habitat stressors indicated a substantial portion of stream length was in most-disturbed condition, west-wide and in Wyoming. Riparian disturbance indicated the percentage of stream length in most-disturbed condition exceeded the percentage in a least-disturbed 
or intermediate condition west-wide and in Wyoming. About 90 percent of the stream length in the xeric climatic region of Wyoming was in the most-disturbed condition for riparian disturbance; smaller percentages of stream length in a most-disturbed condition were observed in the other climatic regions. Two other physical habitat stressors, riparian vegetation and in-stream habitat complexity, indicated the percentage of stream length in a most-disturbed condition was somewhat higher in Wyoming (statewide) than westwide, and the percentages by climatic region also were higher in Wyoming than west-wide. The percentages of condition classes for streambed stability tended to be similar in Wyoming to the percentages observed Westwide. Streambed stability was in the least-disturbed condition at a larger proportion of stream length in the mountain climatic region than in the other climatic regions, relative to reference conditions in each climatic region.

EMAP data from Wyoming also were analyzed using a macroinvertebrate MMI (the Wyoming Stream Integrity Index (WSII)) and an O/E index developed by the State of Wyoming. Narrative ratings determined from the WSII and the O/E index then were used in a matrix to determine suitability for aquatic life use (ALU). Major findings from the ALU assessment were:

- The Wyoming macroinvertebrate MMI indicated most streams were in full support of their ALU. Percentages of streams in various disturbance categories generally were similar between the WSII and the EMAP MMI on both the statewide and climatic region basis. Exceptions occurred in the mountain climatic region, where the WSII assigned a larger percentage of stream length (34 percent) to the most-disturbed condition than the 20 percent assigned by the EMAP MMI, and in the plains climatic region. Differences between the WSII and the EMAP MMI in the plains climatic region could well be caused by the small number of sites available for testing and possible differences in reference conditions.

- The Wyoming O/E assigned more stream length in Wyoming to the full-support condition than either the partial/non-support or indeterminate condition categories. Appreciable differences were noted in biological condition assigned by the Wyoming $\mathrm{O} / \mathrm{E}$ compared to the EMAP O/E at both the statewide and climatic region scales. For example, the EMAP O/E model assigned 58 percent of the stream length statewide to the least-disturbed (full-support) condition, compared to 43 percent assigned by the Wyoming O/E model.
- The statewide ALU matrix results by stream length indicated 52 percent achieves, 16 percent was undetermined, and 32 percent exceeded the State's narrative aquatic life use criteria. The xeric climatic region had the largest percentage of stream length (66 percent) that achieved the ALU criteria, and the mountain climatic region had 51 percent in the achieved ALU condition.

In conclusion, the probabilistic design of the EMAP study provides a foundation and example for future monitoring in Wyoming. The WDEQ incorporated a probability survey component into the State monitoring strategy in 2004 and plans to do so for the foreseeable future.

\section{References Cited}

Barbour, M.T., Gerritsen, J., Snyder, B.D., and Stribling, J.B., 1999, Rapid bioassessment protocols for use in streams and wadeable rivers: periphyton, benthic macroinvertebrates and fish, second edition: U.S. Environmental Protection Agency, EPA 841-B-99-002 [variously paged].

Gerth, W.J., and Herlihy, A.T., 2006, Effect of sampling different habitat types in regional macroinvertebrate bioassessment surveys: Journal of the North American Benthological Society, v. 25, no. 2, p. 501-512.

Hall, R.O., Jr., Tank, J.L., and Dybdahl, M.F., 2003, Exotic snails dominate nitrogen and carbon cycling in a highly productive stream: Frontiers in Ecology and the Environment, v. 1 , no. 8 , p. 407-411.

Hargett, E.G., and Zumberge, J.R., 2006, Redevelopment of the Wyoming Stream Integrity Index (WSII) for assessing the biological condition of wadeable streams of Wyoming: Cheyenne, Wyoming Department of Environmental Quality, Water Quality Division Report, 70 p.

Hargett, E.G., Zumberge, J.R., and Hawkins, C.P., 2005, Development of a RIVPACS model for wadeable streams of Wyoming: Cheyenne, Wyoming Department of Environmental Quality, Water Quality Division Report, 64 p.

Hargett, E.G., Zumberge, J.R., Hawkins, C.P., and Olson, J.R., in press, Development of a RIVPACS-type predictive model for bioassessment of wadeable streams in Wyoming: Ecological Indicators.

Hawkins, C.P., 2006, Quantifying biological integrity by taxonomic completeness-Evaluation of a potential indicator for use in regional and global-scale assessments: Ecological Applications, v. 16, p. 1,277-1,294. 
Hawkins, C.P., Norris, R.H., Hogue, J.N., and Feminella, J.W., 2000, Development and evaluation of predictive models for measuring the biological integrity of streams: Ecological Applications, v. 10, p. 1,456-1,477.

Hughes, R.M., Paulsen, S.G., and Stoddard, J.L., 2000, EMAP-Surface Waters-A multiassemblage, probability survey of ecological integrity in the U.S.A.: Hydrobiologia, v. 422/423, p. 429-443.

Karr, J.R., 1991, Biological integrity-A long-neglected aspect of water resource management: Ecological Applications, v. 1 , no. 1 , p. 66-84.

Kaufmann, P.R., Levine, P., Robison, E.G., Seeliger, C., and Peck, D.V., 1999. Quantifying physical habitat in wadeable streams: Washington, D.C., U.S. Environmental Protection Agency Report EPA/600/3-88/021a, 102 p.

Koel, T.M., Bigelow, P.E., Doepke, P.D., Ertel, B.D., and Mahony, D.L., 2005, Nonnative lake trout result in Yellowstone cutthroat trout decline and impacts to bears and anglers: Fisheries, v. 30, no. 11, p. 10-19.

Lazorchak, J.M., McCormick, F.H., Henry, T.R., and Herlihy, A.T., 2003, Contamination of fish in streams of the midAtlantic Region-An approach to regional indicator selection and wildlife assessment: Environmental Toxicology and Chemistry, v. 22, p. 545-553.

Lazorchak, J.M., Hill, B.H., Averill, D.K., Peck, D.V., and Klemm, D.J., 2000, Environmental Monitoring and Assessment Program-surface waters: Field operations and methods for measuring the ecological condition of non-wadeable rivers and streams: U.S. Environmental Protection Agency Report EPA/620/R-00/007, 204 p.

McDonald, M.E., Paulsen, S., Blair, R., Dlugosz, J., Hale, S., Hedtke, S., Heggem, D., Jackson, L., Jones, K.B., Levinson, B., Olsen, A.R., Stoddard, J., Summers, K., and Veith, G., 2002, Research strategy_Environmental Monitoring and Assessment Program: U.S. Environmental Protection Agency Report EPA 620/R-02/002, 78 p.

Munn, M.D., and Hamilton, P.A., 2003, New studies initiated by the U.S. Geological Survey-Effects of nutrient enrichment on stream ecosystems: U.S. Geological Survey Fact Sheet 118-03, 4 p.

Omernik, J.M., 1987, Ecoregions of the conterminous United States: Annals of the Association of American Geographers, v. 77, no. 1, p. 118-125, 1 pl., scale 1:7,500,000.
Peck, D.V., Herlihy, A.T., Hill, B.H., Hughes, R.M., Kaufmann, P.R., Klemm, D.J., Lazorchak, J.M., McCormick, F.H., Peterson, S.A., Ringold, P.L., Magee, T., and Cappaert, M.R., 2006, Environmental Monitoring and Assessment Program-Surface Waters Western Pilot Study_Field operations manual for wadeable streams: U.S. Environmental Protection Agency Report EPA 620/R-06/003, 276 p.

Peterson, D.A., and Porter, S.D., 2002, Biological and chemical indicators of eutrophication in the Yellowstone River and major tributaries during August 2000: Madison, Wisc., Proceedings of the 2002 National Monitoring Conference, National Water Quality Monitoring Council, 14 p.

Peterson, S.A., Van Sickle, J., Herlihy, A.T., and Hughes, R.M., 2007, Mercury concentration in fish from streams and rivers throughout the western United States: Environmental Science and Technology, v. 41, p. 58-65.

Rehn, A.C., Ode, P.R., and Hawkins, C.P., 2007, Comparisons of targeted-riffle and reach-wide benthic macroinvertebrate samples-Implications for data sharing in stream condition assessments: Journal of the North American Benthological Society, v. 26, p. 332-348.

Richards, D.R., 2002, The New Zealand mudsnail invades: Aquatic Nuisance Species Digest, v. 4, no. 4, p. 42-44.

Stoddard, J.L., 2001, EMAP-West CommunicationsMonitoring the condition of surface waters in the western U.S.: U.S. Environmental Protection Agency Report EPA A620/R-01/004a, 1 p.

Stoddard, J.L., Larsen, D.P., Hawkins, C.P., Johnson, R.K., and Norris, R.H., 2006, Setting expectations for the ecological condition of streams-The concept of reference condition: Ecological Applications, v. 16, p. 1,267-1,276.

Stoddard, J.L., Peck, D.V., Olsen, A.R., Larsen, D.P., Van Sickle, J., Hawkins, C.P., Hughes, R.M., Whittier, T.R., Lomnicky, G.A., Herlihy, A.T., Kaufman, P.R., Peterson, S.A., Ringold, P.L., Paulsen, S.G., and Blair, R., 2005a, Environmental Monitoring and Assessment Program (EMAP) western streams and rivers statistical summary: U.S. Environmental Protection Agency Report 620/R05/006, 1,762 p.

Stoddard, J.L., Peck, D.V., Paulsen, S.G., Van Sickle, J., Hawkins, C.P., Herlihy, A.T., Hughes, R.M., Kaufman, P.R., Larsen, D.P., Lomnicky, G.A., Olsen, A.R., Peterson, S.A., Ringold, P.L., and Whittier, T.R., 2005b, An ecological assessment of western streams and rivers: U.S. Environmental Protection Agency Report 620/R-05/005, 49 p. 
U.S. Environmental Protection Agency, 2000, Mid-Atlantic Highland stream assessment: EPA-903-R-00-015, 64 p.

U.S. Environmental Protection Agency, 2006, Wadeable streams assessment-The States assess the Nation's streams: EPA Report 841/B-06/002, 86 p.

U.S. Environmental Protection Agency, 2007, Mercury home page, accessed May 18, 2007, at http://www.epa.gov/ mercury/

Vallentyne, J.R., 1974, The algal bowl—Lakes and man: Ottawa, Environment Canada miscellaneous special publication 22, $186 \mathrm{p}$.

Van Sickle, J., Hawkins, C.P., Larsen, D.P., and Herlihy, A.T., 2005, A null model for the expected macroinvertebrate assemblage in streams: Journal of the North American Benthological Society, v. 24, p. 178-191.

Waite, I.R., Herlihy, R.A., Larsen, D.P., and Klemm, D.J., 2000, Comparing strengths of geographic and nongeographic classifications of stream benthic macroinvertebrates in the mid-Atlantic Highlands, USA: Journal of the North American Benthological Society, v. 19, p. 429-441.

Whittier, T.R., Hughes, R.M., Stoddard, J.L., Lomnicky, G.A., Peck, D.V., and Herlihy, A.T., 2007a, A structured approach for developing indices of biotic integrity-Three examples from western streams and rivers in the USA: Transactions of the American Fisheries Society, v. 136, no. 3, p. 718-735.

Whittier, T.R., Stoddard, J.L., Larsen, D.P., and Herlihy, A.T., 2007b, Selecting reference sites for stream biological assessments-Best professional judgment or objective criteria: Journal of the North American Benthological Society, v. 26, p. $349-360$.

Wyoming Department of Environmental Quality, 1999, Manual of standard operating procedures for sample collection and analysis: Cheyenne, Wyoming, $374 \mathrm{p}$.

Wyoming Department of Environmental Quality, 2001, Water quality rules and regulations, chapter 1 , Wyoming surface water quality standards: Cheyenne, Wyoming, $25 \mathrm{p}$.

Wyoming Department of Environmental Quality, 2006, Wyoming's draft 2006 305(b) State water quality assessment report and draft 2006 303(d) list of waters requiring TMDLs, accessed November 9, 2006, at http://deq.state. wy.us/wqd/watershed/index.asp

Zumberge, J.R., 2004, Water quality monitoring strategy, accessed July 17, 2007, at http://deq.state.wy.us/wqd/ watershed/Downloads/Monitoring/4-066doc.pdf, $18 \mathrm{p}$. 


\section{Appendixes}



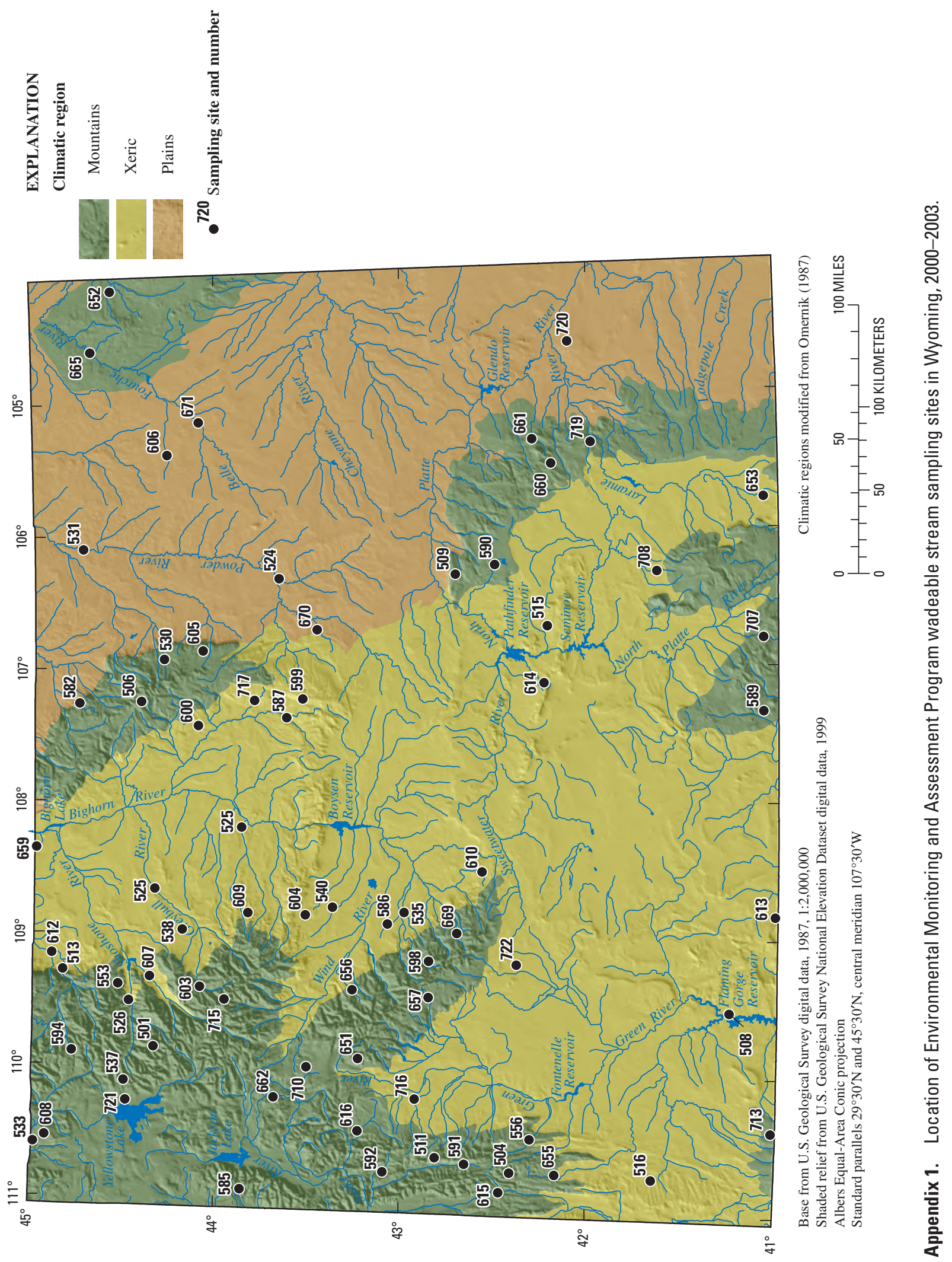
Appendix 2. Environmental Monitoring and Assessment Program wadeable stream sampling sites in Wyoming, 2000-2003.

\begin{tabular}{|c|c|c|c|c|}
\hline $\begin{array}{l}\text { Site number } \\
\text { (Appendix 1) }\end{array}$ & Stream name & Year sampled & Latitude & Longitude \\
\hline 501 & Unnamed tributary to Ruth Creek & 2000 & 44.346 & -109.854 \\
\hline 504 & Alice Creek & 2000 & 42.414 & -110.724 \\
\hline 506 & North Paint Rock Creek & 2000 & 44.427 & -107.255 \\
\hline 508 & Currant Creek & 2000 & 41.255 & -109.525 \\
\hline 509 & Elkhorn Creek & 2000 & 42.735 & -106.322 \\
\hline 511 & Sheep Creek & 2000 & 42.816 & -110.629 \\
\hline 513 & Clarks Fork Yellowstone River & 2000 & 44.842 & -109.280 \\
\hline 515 & South Fork Sage Creek & 2000 & 42.244 & -106.708 \\
\hline 516 & Little Muddy Creek & 2000 & 41.653 & -110.746 \\
\hline 524 & Salt Creek & 2000 & 43.683 & -106.339 \\
\hline 525 & Cottonwood Creek & 2000 & 43.887 & -108.197 \\
\hline 526 & Big Creek & 2000 & 44.483 & -109.508 \\
\hline 530 & Hondo Creek & 2000 & 44.303 & -106.938 \\
\hline 531 & Powder River & 2000 & 44.733 & -106.102 \\
\hline 533 & Blacktail Deer Creek & 2000 & 44.982 & -110.592 \\
\hline 535 & Trout Creek & 2000 & 43.008 & -108.822 \\
\hline 537 & Crow Creek & 2001 & 44.504 & -110.117 \\
\hline 538 & Meeteetse Creek & 2000 & 44.201 & -108.979 \\
\hline 540 & Fivemile Creek & 2000 & 43.390 & -108.797 \\
\hline 553 & Trout Creek & 2003 & 44.543 & -109.383 \\
\hline 556 & La Barge Creek & 2003 & 42.310 & -110.475 \\
\hline 582 & Wolf Creek & 2001 & 44.760 & -107.264 \\
\hline 585 & North Leigh Creek & 2001 & 43.859 & -110.909 \\
\hline 586 & Sage Creek & 2001 & 43.097 & -108.909 \\
\hline 587 & Nowood River & 2001 & 43.646 & -107.379 \\
\hline 589 & Unnamed tributary to Big Gulch & 2001 & 41.084 & -107.333 \\
\hline 590 & Mud Springs Draw & 2001 & 42.523 & -106.255 \\
\hline 591 & Greys River & 2001 & 42.657 & -110.671 \\
\hline 592 & Little Greys River & 2001 & 43.095 & -110.745 \\
\hline 594 & Unnamed tributary to Timber Creek & 2001 & 44.786 & -109.892 \\
\hline 598 & Gaylord Creek & 2001 & 42.873 & -109.180 \\
\hline 599 & Cherry Creek & 2001 & 43.560 & -107.239 \\
\hline 600 & Brokenback Creek & 2001 & 44.121 & -107.437 \\
\hline 603 & Warhouse Creek & 2001 & 44.102 & -109.398 \\
\hline 604 & Bargee Creek & 2001 & 43.540 & -108.849 \\
\hline 605 & Poison Creek & 2001 & 44.095 & -106.876 \\
\hline 606 & Donkey Creek & 2001 & 44.274 & -105.401 \\
\hline 607 & South Fork Shoshone River & 2001 & 44.373 & -109.324 \\
\hline 608 & Unnamed tributary to Blacktail Deer Creek & 2001 & 44.921 & -110.537 \\
\hline 609 & Little Grass Creek & 2001 & 43.849 & -108.837 \\
\hline
\end{tabular}


Appendix 2. Environmental Monitoring and Assessment Program wadeable stream sampling sites in Wyoming, 2000-2003.-Continued

\begin{tabular}{|c|c|c|c|c|}
\hline $\begin{array}{l}\text { Site number } \\
\text { (Appendix 1) }\end{array}$ & Stream name & Year sampled & Latitude & Longitude \\
\hline 610 & Twin Creek & 2001 & 42.592 & -108.516 \\
\hline 612 & Bennett Creek & 2001 & 44.903 & -109.153 \\
\hline 613 & Canyon Creek & 2001 & 41.015 & -108.827 \\
\hline 614 & Miners Canyon & 2001 & 42.263 & -107.124 \\
\hline 615 & Water Canyon Creek & 2001 & 42.469 & -110.870 \\
\hline 616 & Hoback River & 2001 & 43.236 & -110.447 \\
\hline 651 & South Fork Gypsum Creek & 2002 & 43.244 & -109.911 \\
\hline 652 & Redwater Creek & 2002 & 44.560 & -104.155 \\
\hline 653 & Spring Creek & 2002 & 41.076 & -105.781 \\
\hline 655 & Hams Fork Green River & 2002 & 42.172 & -110.730 \\
\hline 656 & Dry Creek & 2002 & 43.282 & -109.401 \\
\hline 657 & Middle Fork Boulder Creek & 2002 & 42.872 & -109.447 \\
\hline 659 & Crooked Creek & 2002 & 44.991 & -108.354 \\
\hline 660 & Bear Creek & 2002 & 42.213 & -105.517 \\
\hline 661 & Cottonwood Creek & 2002 & 42.312 & -105.337 \\
\hline 662 & South Fork Spread Creek & 2002 & 43.693 & -110.214 \\
\hline 665 & Blacktail Creek & 2002 & 44.676 & -104.611 \\
\hline 669 & Middle Popo Agie River & 2002 & 42.724 & -108.971 \\
\hline 670 & Willow Creek & 2002 & 43.480 & -106.723 \\
\hline 671 & Belle Fourche River & 2002 & 44.102 & -105.159 \\
\hline 707 & Encampment River & 2003 & 41.083 & -106.797 \\
\hline 708 & Wagonhound Creek & 2003 & 41.653 & -106.313 \\
\hline 710 & Leeds Creek & 2003 & 43.520 & -109.982 \\
\hline 713 & East Fork Smiths Fork & 2003 & 41.018 & -110.387 \\
\hline 715 & Unnamed tributary to Venus Creek & 2003 & 43.970 & -109.489 \\
\hline 716 & Horse Creek & 2003 & 42.933 & -110.200 \\
\hline 717 & South Fork Otter Creek & 2003 & 43.818 & -107.248 \\
\hline 719 & Duck Creek & 2003 & 41.999 & -105.366 \\
\hline 720 & Deer Creek & 2003 & 42.110 & -104.628 \\
\hline 721 & Cub Creek & 2003 & 44.490 & -110.261 \\
\hline 722 & Little Mitchell Slough & 2003 & 42.402 & -109.197 \\
\hline
\end{tabular}


Prepared by the Helena Publishing Service Center

For additional information contact:

Director, Wyoming Water Science Center

U.S. Geological Survey

2617 East Lincolnway Avenue, Suite B

Cheyenne, Wyoming 82001

(307) 778-2931

http://wy.water.usgs.gov/ 

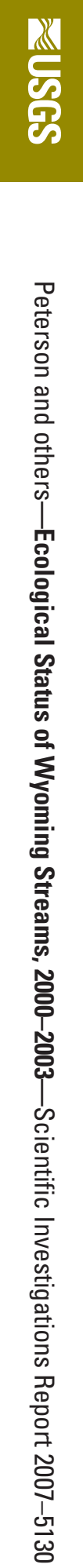

9 Printed on recycled paper 